\title{
The ability of macroalgae to mitigate the negative effects of ocean acidification on four species of North Atlantic bivalve
}

\author{
Craig S. Young and Christopher J. Gobler \\ Stony Brook University, School of Marine and Atmospheric Sciences, Southampton, NY 11968, USA \\ Correspondence: Christopher J. Gobler (christopher.gobler@ stonybrook.edu)
}

Received: 2 March 2018 - Discussion started: 29 March 2018

Revised: 17 September 2018 - Accepted: 9 October 2018 - Published: 23 October 2018

\begin{abstract}
Coastal ecosystems can experience acidification via upwelling, eutrophication, riverine discharge, and climate change. While the resulting increases in $p \mathrm{CO}_{2}$ can have deleterious effects on calcifying animals, this change in carbonate chemistry may benefit some marine autotrophs. Here, we report on experiments performed with North Atlantic populations of hard clams (Mercenaria mercenaria), eastern oysters (Crassostrea virginica), bay scallops (Argopecten irradians), and blue mussels (Mytilus edulis) grown with and without North Atlantic populations of the green macroalgae, Ulva. In six of seven experiments, exposure to elevated $p \mathrm{CO}_{2}$ levels $(\sim 1700 \mu \mathrm{atm})$ resulted in depressed shell- and/or tissuebased growth rates of bivalves compared to control conditions, whereas rates were significantly higher in the presence of Ulva in all experiments. In many cases, the co-exposure to elevated $p \mathrm{CO}_{2}$ levels and Ulva had an antagonistic effect on bivalve growth rates whereby the presence of Ulva under elevated $p \mathrm{CO}_{2}$ levels significantly improved their performance compared to the acidification-only treatment. Saturation states for calcium carbonate $(\Omega)$ were significantly higher in the presence of Ulva under both ambient and elevated $\mathrm{CO}_{2}$ delivery rates, and growth rates of bivalves were significantly correlated with $\Omega$ in six of seven experiments. Collectively, the results suggest that photosynthesis and/or nitrate assimilation by Ulva increased alkalinity, fostering a carbonate chemistry regime more suitable for optimal growth of calcifying bivalves. This suggests that large natural and/or aquacultured collections of macroalgae in acidified environments could serve as a refuge for calcifying animals that may otherwise be negatively impacted by elevated $p \mathrm{CO}_{2}$ levels and depressed $\Omega$.
\end{abstract}

\section{Introduction}

The continued delivery of $\mathrm{CO}_{2}$ into surface oceans is expected to cause significant shifts in pools of inorganic carbon by the end of this century, with projected increases in $\mathrm{CO}_{2}$ and $\mathrm{HCO}_{3}^{-}$and decreases in $\mathrm{CO}_{3}^{2-}$ and the saturation states of calcite ( $\left.\Omega_{\text {calcite }}\right)$ and aragonite $\left(\Omega_{\text {aragonite }}\right)$ (Feely et al., 2009; Meehl et al., 2007). Beyond the delivery of $\mathrm{CO}_{2}$ via the combustion of fossil fuels, upwelling, riverine discharge, and eutrophication-accelerated microbial respiration all represent strong sources of $\mathrm{CO}_{2}$ into coastal zones (Cai et al., 2011; Feely et al., 2008; Melzner et al., 2013; Salisbury et al., 2008; Wallace et al., 2014). Eutrophication-enhanced respiration in coastal zones can lead to the accumulation of respiratory $\mathrm{CO}_{2}$ that can exceed concentrations projected for the end of the century ( $>2000 \mu \mathrm{atm})$, as well as result in the undersaturation of aragonite $\left(\Omega_{\text {aragonite }}<1\right.$; Cai et al., 2017; Wallace et al., 2014).

Calcifying organisms are highly vulnerable to the projected shifts in the various pools of total dissolved inorganic carbon (DIC), with the deleterious effects of ocean acidification being well documented for corals (Hoegh-Guldberg et al., 2007; Kleypas et al., 1999), coralline algae (Gao and Zheng, 2010; Martin and Gattuso, 2009), and bivalves (Barton et al., 2012; Gazeau et al., 2007; Talmage and Gobler, 2011). Acidification-induced reductions in $\Omega_{\text {calcite }}$ and $\Omega_{\text {aragonite }}$ can result in lowered survivorship and inhibited growth for larvae and juvenile stage bivalves (Gobler et al., 2014; Green et al., 2009; Talmage and Gobler, 2011; Waldbusser et al., 2015a). Since bivalves provide numerous ecosystem and economic services (Newell, 2004), and elevated $p \mathrm{CO}_{2}$ is a common occurrence in many coastal ecosystems (Feely et al., 2008; Salisbury et al., 2008; Wallace et al., 2014), it is important to understand how other co-occurring 
estuarine life will respond to high- $p \mathrm{CO}_{2}$ conditions and may, in turn, affect acidification-vulnerable organisms such as bivalves.

Contrary to the negative effects of increased $\mathrm{CO}_{2}$ on calcifying organisms, previous studies have shown that some photosynthetic organisms, such as seagrasses (Koch et al., 2013; Palacios and Zimmerman, 2007), phytoplankton (Fu et al., 2012; Hattenrath-Lehmann et al., 2015), and macroalgae (Olischläger et al., 2013; Young and Gobler, 2016), may benefit from a high- $\mathrm{CO}_{2}$ environment. Such photosynthetic autotrophs may also have the capacity to buffer carbonate chemistry, potentially alleviating the harmful effects of excessive $\mathrm{CO}_{2}$ on calcifying organisms. For example, prior studies have observed that daytime productivity within seagrass meadows can increase $\mathrm{pH}$ and $\Omega_{\text {aragonite, which, un- }}$ der future acidified conditions, may provide temporal refuge for calcifying animals (Garrard et al., 2014; Hendriks et al., 2014). Given the significant global declines in seagrass (Orth et al., 2006; Short et al., 2011; Waycott et al., 2009), as well as the overgrowth of seagrass beds by macroalgae (McGlathery, 2001; Valiela et al., 1997), it is plausible macroalgae may more commonly provide similar ecosystem services. While future increases in $\mathrm{CO}_{2}$ may promote the growth of fast-growing macroalgae such as Ulva (Björk et al., 1993; Olischläger et al., 2013; Young and Gobler, 2016, 2017) and could, in turn, provide chemical resilience for calcifying organisms in acidified environments (Anthony et al., 2013; Wahl et al., 2017), such interactions have yet to be fully explored.

Recent studies have demonstrated that populations of Ulva rigida from northwest Atlantic coastal waters experience enhanced growth under elevated $\mathrm{CO}_{2}$ concentrations (Young and Gobler, 2016, 2017). While past studies have suggested that macroalgae may buffer carbonate chemistry to the benefit of bivalves (Anthony et al., 2013; Wahl et al., 2017), no study has assessed how Ulva, a common macroalga known to undergo enhanced growth under acidified and eutrophic conditions, may affect bivalves under $\mathrm{CO}_{2}$-enhanced conditions. The objective of this study, therefore, was to assess how elevated $p \mathrm{CO}_{2}$ and the presence of Ulva influences the growth and survival of seven cohorts of juvenile bivalves indigenous to the North Atlantic, including hard clams (= northern quahogs; Mercenaria mercenaria), eastern oysters (Crassostrea virginica), bay scallops (Argopecten irradians), and blue mussels (Mytilus edulis). Small- and large-sized individuals of bivalves were assessed for three species given the effects of ocean acidification can be size and species dependent for juvenile bivalves (Talmage and Gobler, 2011; Waldbusser et al., 2010). Each bivalve cohort was grown with and without elevated $\mathrm{CO}_{2}$ levels as well as with and without Ulva. Growth and survival of the bivalves were quantified along with carbonate chemistry within experimental vessels.

\section{Methods}

\subsection{Experimental design}

Seven experiments were performed to assess the effects of elevated $p \mathrm{CO}_{2}$ and the presence of Ulva on the growth and survival of $M$. mercenaria, C. virginica, A. irradians, and $M$. edulis. Experiments using smaller bivalves $(1-5 \mathrm{~mm})$ were performed in $1 \mathrm{~L}$ polycarbonate vessels, while experiments with larger bivalves $(20-21 \mathrm{~mm})$ were performed in larger $8 \mathrm{~L}$ polycarbonate vessels. All containers were acid washed $(10 \% \mathrm{HCl})$ and liberally rinsed with deionized water prior to use. The experimental vessels were placed in an environmental control chamber set to a consistent temperature $\left(\sim 21^{\circ} \mathrm{C}\right)$, light intensity $\left(\sim 200 \mu\right.$ mol photons $\left.\mathrm{m}^{-2} \mathrm{~s}^{-1}\right)$, and duration ( $14 \mathrm{~h}: 10 \mathrm{~h}$, light : dark cycle). The light intensity and photoperiod were set to mimic conditions observed at the Ulva collection sites during the time of collection (see below). Containers were filled with filtered $(0.2 \mu \mathrm{m}$ polysulfone filter capsule, Pall@) seawater and were randomly assigned, in quadruplicate, to one of four treatments: a control with ambient $\mathrm{CO}_{2}$ concentrations $(\sim 400 \mu \mathrm{atm})$ without Ulva, a treatment with ambient $\mathrm{CO}_{2}$ levels that received Ulva, a treatment with elevated $\mathrm{CO}_{2}$ concentrations $(\sim 1700 \mu \mathrm{atm})$ without $U l v a$, and a treatment with elevated $\mathrm{CO}_{2}$ and Ulva, resulting in 16 experimental containers. Two additional containers were filled with filtered seawater and bubbled in a manner identical to the ambient or elevated $\mathrm{CO}_{2}$ treatments (described below) and were used to obtain initial DIC measurements. Continuous dissolved oxygen measurements were made using HOBO optical dissolved oxygen sensors $($ Onset@) in additional parallel vessels with and without Ulva added at the same levels used in experimental vessels and bubbled identically to experimental vessels. All experimental containers for each experiment received nutrient additions ( $50 \mu \mathrm{M}$ nitrate, $3 \mu \mathrm{M}$ phosphate) at the beginning of the experiment, as well as after each twice-weekly water changes (details below) to ensure nutrient-replete growth of Ulva. The nutrient and $\mathrm{CO}_{2}$ concentrations used during experiments were within the range of concentrations present in US East Coast estuaries (Baumann and Smith, 2018; Baumann et al., 2015; Wallace et al., 2014; Wallace and Gobler, 2015) and were used during prior experiments that involved Ulva from Shinnecock Bay, NY, USA (Young and Gobler, 2016, 2017). Across all experiments, bivalves were fed a mixture of Isochrysis galbana and Chaetoceros muelleri at a rate known to be ad libitum $\left(4 \times 10^{4}\right.$ cells $\mathrm{mL}^{-1} \mathrm{~d}^{-1}$; Helm et al., 2004). Microalgal cultures were maintained in exponential phase growth in $\mathrm{f} / 2$ media using standard culturing conditions (Helm et al., 2004).

To deliver dissolved gases, each experimental vessel was aerated via a $3.8 \times 1.3 \mathrm{~cm}$ air diffuser (Pentair) connected to a $1 \mathrm{~mL}$ polystyrene serological pipette inserted into the bottom of each vessel and connected via Tygon tubing to an air source. Containers were subjected to ambient $(\sim$ 
$400 \mu \mathrm{atm})$ and elevated $(\sim 1700 \mu \mathrm{atm}) \mathrm{CO}_{2}$ concentrations via a gas proportionator system $\left(\right.$ Cole Parmer ${ }^{\circledR}$ flowmeter system, multi-tube frame) that mixed ambient air with $5 \%$ $\mathrm{CO}_{2}$ gas (Talmage and Gobler, 2010). Gases were mixed and delivered at a flow rate of $2500 \pm 5 \mathrm{~mL} \mathrm{~min}^{-1}$ through gang valves into the serological pipettes that fit through an opening in the plexiglass used to cover the experimental containers, turning over the volume of the experimental containers $>1000$ times daily. Bubbling began 2 to 3 days prior to the start of each experiment to allow $\mathrm{CO}_{2}$ concentrations and carbonate chemistry to reach a state of equilibrium. Experiments persisted for $\sim 2$ weeks. Measurements of $\mathrm{pH}$ within containers were made daily with a Honeywell Durafet III ion-sensitive field-effect transistor-based (ISFET) solid-state $\mathrm{pH}$ sensor $( \pm 0.01 \mathrm{pH}$ unit, total scale), which was calibrated with a seawater $\mathrm{pH}$ standard (Dickson, 1993). In select experimental containers throughout the duration of experiments, continuous measurements of $\mathrm{pH}$ were made using an Orion Star A321 Plus electrode $( \pm 0.001 \mathrm{pH}$ unit, NBS scale) calibrated prior to use using National Institute of Standards and Technology (NIST) traceable standards. Measurements of $\mathrm{pH}$ made with the Durafet and Orion instruments were compared to measurements made spectrophotometrically using $m$-cresol purple (Dickson et al., 2007) and were found to be nearly identical and never significantly different. Discrete water samples were collected at the beginning and conclusion of experiments to directly measure DIC within each experimental vessel in each treatment $(n=4$ per treatment). The DIC samples were preserved using a saturated mercuric chloride $\left(\mathrm{HgCl}_{2}\right)$ solution and stored at $\sim 4{ }^{\circ} \mathrm{C}$ until analysis. Samples were analyzed by a VINDTA 3-D (versatile instrument for the determination of total inorganic carbon) delivery system coupled with a UIC Inc. coulometer (model CM5017O). During the coulometric analysis, all carbonate species were converted to $\mathrm{CO}_{2}$ gas by the addition of excess hydrogen to the sample and the evolved $\mathrm{CO}_{2}$ gas was subsequently carried into the titration cell of the coulometer. The gas then reacted quantitatively with an ethanolamine-based reagent to generate hydrogen ions, which were titrated with coulometrically generated $\mathrm{OH}^{-}$, and $\mathrm{CO}_{2}$ was measured by integrating the total change required to titrate the hydrogen ions (Johnson et al., 1993). Final total alkalinity, $\Omega_{\text {aragonite }}, \Omega_{\text {calcite }}, p \mathrm{CO}_{2}$, and concentrations of $\mathrm{HCO}_{3}^{-}, \mathrm{CO}_{3}^{2-}$, and $\mathrm{OH}^{-}$(Tables 1 and $\mathrm{S} 1$ in the Supplement) were calculated from measured levels of DIC, $\mathrm{pH}$, temperature, and salinity, as well as the first and second dissociation constants of carbonic acid in seawater (Millero, 2010) using the program CO2SYS (http://cdiac.ess-dive.lbl. gov/ftp/co2sys/, last access: 17 October 2018). For quality assurance, levels of DIC and $\mathrm{pH}$ within certified reference material (provided by Andrew Dickson of the University of California, San Diego, Scripps Institution of Oceanography; batches $158,159=2044,2027 \mu$ mol DIC kg seawater ${ }^{-1}$, respectively) were measured during analyses of every set of samples. The analysis of samples continued only after complete recovery $(99.8 \pm 0.2 \%)$ of certified reference material was attained. Actual mean $p \mathrm{CO}_{2}$ and $\mathrm{pH}$ values were 350 and $8.00 \mu \mathrm{atm}$, respectively for ambient conditions and 1750 and $7.38 \mu \mathrm{atm}$, respectively, for elevated $\mathrm{CO}_{2}$ conditions, values within the range found seasonally in some estuarine environments (Baumann and Smith, 2018; Baumann et al., 2015; Wallace et al., 2014; Wallace and Gobler, 2015). Two-way ANOVA and post hoc tests were used to assess significant differences in carbonate chemistry among experimental vessels with the main treatment effects being $p \mathrm{CO}_{2}$ (ambient or elevated) and the presence of Ulva within SigmaPlot 11.0.

\subsection{Assessing the effects of elevated $p \mathrm{CO}_{2}$ and Ulva on juvenile bivalves}

The macroalgae used for this study were collected from Shinnecock Bay, NY, USA $\left(40.85^{\circ} \mathrm{N}, 72.50^{\circ} \mathrm{W}\right)$ during low tide. Permission to access this area and collect macroalgae and M. edulis was received from the Southampton Town Trustees, Southampton, NY, USA, who hold jurisdiction over Shinnecock Bay. Large, well-pigmented, robust fronds of Ulva were collected and transported to the Stony Brook Marine Science Center in seawater-filled containers within 15 min of collection. Previously, internal transcribed spacer (ITS) sequencing and microscopy was used to determine that the species of Ulva that dominated Shinnecock Bay in summer and fall was Ulva rigida (Young and Gobler, 2016, 2017), and microscopic examinations during this study indicated this was the species used in all experiments presented here. We refer to the algae simply as Ulva throughout the study due to the plastic nature of the macroalgal taxonomic nomenclature, as well as the high similarity of ITS sequences among species of Ulva (Hofmann et al., 2010; Kirkendale et al., 2013).

Well-pigmented, circular sections of Ulva $(\sim 3.5$ and $\sim$ $7 \mathrm{~cm}$ for experiments in small containers and large vessels (described below), respectively, with one disk per container) were cut from the larger thalli, with care taken to avoid the outer, potentially reproductive region of the algae (Wallace and Gobler, 2015). The weights of Ulva used in experiments relative to the vessels were consistent with the benthic coverage of Ulva in Shinnecock Bay $\left(\sim 8 \mathrm{~g} \mathrm{~m}^{-2}\right.$; Christopher Gobler and Craig Young, unpublished benthic trawl data, 2017) and other estuarine regions (Liu et al., 2015; Sfriso et al., 2001). Experimental disks of Ulva were extensively rinsed with filtered $(0.2 \mu \mathrm{m})$ seawater and spun in a salad spinner to remove debris and epiphytes, with this step being repeated multiple times. Ulva samples were weighed on a Scientech ZSA-120 digital microbalance $( \pm 0.0001 \mathrm{~g})$ to obtain initial wet weight in grams. All samples were kept in $100 \mathrm{~mL} 0.2 \mu \mathrm{m}$ filtered seawater-filled containers after spinning and weighing to prevent desiccation prior to use in experiments. 
Table 1. Values of mean $\mathrm{pH}$ (total scale), temperature $\left({ }^{\circ} \mathrm{C}\right)$, dissolved oxygen $\left(\mathrm{mg} \mathrm{L}^{-1}\right)$, and salinity $\left(\mathrm{g} \mathrm{kg}^{-1}\right)$, and final $p \mathrm{CO}_{2}(\mu a t m)$, total alkalinity $\left(\mu \mathrm{mol} \mathrm{kg} \mathrm{SW}{ }^{-1}\right)$, total DIC $\left(\mu \mathrm{mol} \mathrm{kg} \mathrm{SW}{ }^{-1}\right), \mathrm{HCO}_{3}^{-}\left(\mu \mathrm{mol} \mathrm{kg} \mathrm{SW}{ }^{-1}\right), \mathrm{CO}_{3}^{2-}\left(\mu \mathrm{mol} \mathrm{kg} \mathrm{SW}{ }^{-1}\right), \mathrm{OH}^{-}\left(\mu \mathrm{mol} \mathrm{kg} \mathrm{SW}^{-1}\right), \Omega_{\mathrm{calcite}}$,

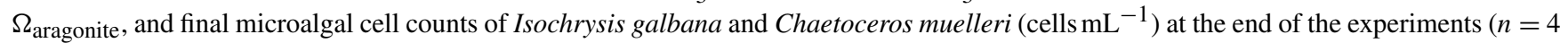
for all treatments). Values represent means \pm standard error. Asterisks indicate parameters that were directly measured and not calculated. Data from individual experiments appear within Table S1.

\begin{tabular}{lrrrr}
\hline Parameter & Control & Ulva & $\mathrm{CO}_{2}$ & $\mathrm{CO}_{2} /$ Ulva \\
\hline $\mathrm{pH}^{*}$ & $7.98 \pm 0.01$ & $8.03 \pm 0.01$ & $7.37 \pm 0.01$ & $7.39 \pm 0.01$ \\
Temperature* & $21.3 \pm 0.1$ & $21.2 \pm 0.1$ & $21.3 \pm 0.1$ & $21.3 \pm 0.1$ \\
Dissolved oxygen* & $9.06 \pm 0.01$ & $9.00 \pm 0.01$ & $9.17 \pm 0.01$ & $9.10 \pm 0.01$ \\
Salinity* & $30.0 \pm 0.1$ & $30.1 \pm 0.1$ & $30.0 \pm 0.1$ & $30.0 \pm 0.1$ \\
$p \mathrm{CO}_{2}$ & $373 \pm 8$ & $335 \pm 9$ & $1763 \pm 27$ & $1721 \pm 27$ \\
Total alkalinity & $1740 \pm 26$ & $1759 \pm 26$ & $1792 \pm 25$ & $1803 \pm 21$ \\
Total DIC* & $1561 \pm 19$ & $1557 \pm 21$ & $1782 \pm 22$ & $1797 \pm 19$ \\
$\mathrm{HCO}_{3}^{-}$ & $1428 \pm 16$ & $1413 \pm 18$ & $1690 \pm 21$ & $1706 \pm 19$ \\
$\mathrm{CO}_{3}^{2-}$ & $119 \pm 4$ & $134 \pm 5$ & $35 \pm 1$ & $37 \pm 1$ \\
$\mathrm{OH}^{-}$ & $3.84 \pm 0.12$ & $4.51 \pm 0.18$ & $0.95 \pm 0.02$ & $1.01 \pm 0.02$ \\
$\Omega_{\text {calcite }}$ & $2.97 \pm 0.11$ & $3.36 \pm 0.13$ & $0.86 \pm 0.03$ & $0.90 \pm 0.03$ \\
$\Omega_{\text {aragonite }}$ & $1.91 \pm 0.07$ & $2.16 \pm 0.09$ & $0.56 \pm 0.02$ & $0.59 \pm 0.02$ \\
Microalgae cells* & $97273 \pm 5230$ & $97727 \pm 4696$ & $90455 \pm 4388$ & $95000 \pm 5294$ \\
\hline
\end{tabular}

Small and large cohorts of Mercenaria mercenaria $(\sim 1$ and $\sim 5 \mathrm{~mm}$, respectively) and Argopecten irradians $(\sim 5$ and $\sim 20 \mathrm{~mm}$, respectively) used during experiments were spawned at the Stony Brook Marine Science Center of the Stony Brook University hatchery $\left(40.89^{\circ} \mathrm{N}, 72.44^{\circ} \mathrm{W}\right)$ using brood stock from Shinnecock Bay collected 1 to 2 months prior to spawning and exposed to environmental conditions (salinity, dissolved oxygen, $\mathrm{pH}$ ) similar to their collection site. Small and large cohorts of Crassostrea virginica $(\sim 2$ and $\sim 20 \mathrm{~mm}$, respectively) used during experiments were produced by the Cornell Cooperative Extension shellfish hatchery, NY, USA $\left(40.04^{\circ} \mathrm{N}, 72.39^{\circ} \mathrm{W}\right)$ using brood stock from the Peconic Estuary, NY, USA. Cohorts of small juvenile Mytilus edulis ( $\sim 5 \mathrm{~mm}$ ) used during experiments were collected from Shinnecock Bay, NY, USA, during low tide $\left(40.84^{\circ} \mathrm{N}, 72.50^{\circ} \mathrm{W}\right)$. Experiments using smaller bivalves $(1-5 \mathrm{~mm})$ were performed in $1 \mathrm{~L}$ polycarbonate vessels with 20 individuals per vessel, while experiments with larger bivalves $(20-21 \mathrm{~mm})$ were performed in larger, $8 \mathrm{~L}$ polycarbonate vessels with five individuals per vessel.

Experiments began with the introduction of bivalves, Ulva, and nutrients into experimental vessels, with discrete measurements of $\mathrm{pH}$ and continuous measurements of dissolved oxygen and temperature made as described above throughout experiments. At the beginning of each experiment, 20 individuals from each bivalve cohort were set aside to obtain initial measurements of shell length (defined here as distance from umbo to furthest ventral margin), tissue weight, and shell weight. Bivalve dimensions were determined via digital calipers and digital images with the two approaches producing nearly identical and not statistically different measurements. Captured images of bivalves were analyzed using ImageJ, with the scale of each image individually calibrated. Every 3 to 4 days, a complete water change was performed for all containers using water bubbled in $20 \mathrm{~L} \mathrm{car}-$ boys with gas mixtures for ambient and elevated $\mathrm{CO}_{2}$ treatments as described above to ensure bivalves were exposed to their respective $\mathrm{CO}_{2}$ concentrations. Once weekly, Ulva disks from each container were removed, rinsed, spun in the salad spinner, weighed, and returned to the vessels. Additionally, every week, bivalves were collected on a $500 \mu \mathrm{m}$ sieve, transferred to a petri dish, and measured for length with any mortality noted. Mortality rates were very low (always $<10 \%$ ) and did not differ among treatments. At the conclusion of experiments, final $\mathrm{pH}$, temperature, and salinity measurements were made and final water samples for DIC analysis were collected and analyzed as described above. Additionally, $50 \mathrm{~mL}$ samples were removed from each container to assess final cell concentrations of phytoplankton provided for food (I. galbana and C. muelleri), which were preserved with Lugol's iodine (5\%) solution and enumerated via microscopy (Tables 1 and $\mathrm{S} 1$ ).

At the conclusion of experiments, measurements of shell length for bivalves within the experimental containers as well as individuals set aside for initial measurements were made, and growth (expressed as $\mathrm{mmd}^{-1}$ ) was determined from the changes in shell dimensions during the experiment. Tissue and shell weight were obtained by weighing bivalves after drying at $60^{\circ} \mathrm{C}$ for $72 \mathrm{~h}$, combusting them at $450^{\circ} \mathrm{C}$ for $4 \mathrm{~h}$, and weighing them again. Growth (expressed as milligrams per day) was determined by comparing the initial and final dry and combusted weights of individuals from each replicated vessel. Specifically, tissue weight was determined by subtracting the combusted weight from the dry weight, while shell weight was determined by subtracting the tissue weight from the dry weight. Two-way ANOVA was 
performed using SigmaPlot 11.0 to assess significant differences in growth rates based on shell length, tissue weight, shell weight, and survival during experiments, for which the main treatment effects were $p \mathrm{CO}_{2}$ (ambient or elevated) and the presence of Ulva. All data were log transformed prior to two-way ANOVA to ensure that the assumptions of equal variance and normality were met. Normality was tested via the use of Shapiro-Wilk tests. If significant differences were detected, a Tukey's honest significant difference (Tukey's HSD) test using R 3.4.0 within RStudio 1.0.143 was performed to identify specific differences among treatments. Finally, linear regression models of growth rates based on shell length, tissue weight, and shell weight with $\Omega_{\text {calcite }}$ and $\Omega_{\text {aragonite }}$ were created using $\mathrm{R}^{\circledR}$ software (version: 3.4.0; http://www.r-project.org, last access: 17 October 2017).

\section{Results}

\subsection{Mercenaria mercenaria}

For the cohort of smaller juvenile $M$. mercenaria $(1.34 \pm$ $0.24 \mathrm{~mm}), \Omega_{\text {calcite }}$ and $\Omega_{\text {aragonite }}$ were significantly lower in treatments with elevated $\mathrm{CO}_{2}$ (two-way ANOVA; $p<0.001$ for both, Fig. 1; Tables S2-S3) and significantly higher in treatments containing Ulva (two-way ANOVA; $p=0.002$ and $p=0.007$, respectively). Growth of the small M. mercenaria based upon shell length, shell weight, and tissue weight was highly sensitive to increases in $p \mathrm{CO}_{2}$ as well as the presence of Ulva. When exposed to elevated $\mathrm{CO}_{2}$ conditions, growth rates based on shell length, shell weight, and tissue weight were $49 \%, 66 \%$, and $41 \%$ lower, respectively, when compared to their counterparts in ambient $\mathrm{CO}_{2}$ treatments (two-way ANOVA; $p<0.001, p<0.001$, and $p=0.038$, respectively; Fig. 1; Tables S4-S6). In contrast, growth rates based on shell length, shell weight, and tissue weight were significantly higher in the presence of Ulva (two-way ANOVA; $p=0.006, p=0.011$, and $p=0.008$, respectively; Fig. 1; Tables S4-S6) with growth based on shell length, tissue weight, and shell weight being $28 \%$, $37 \%$, and $47 \%$ higher, respectively, within elevated $\mathrm{CO}_{2}$ treatments and $10 \%, 25 \%$, and $30 \%$, respectively, within ambient $\mathrm{CO}_{2}$ treatments (Fig. 1). Multiple comparison tests revealed that Ulva often mitigated the negative effects of elevated $\mathrm{CO}_{2}$ on hard clams. For example, length-based growth in elevated $\mathrm{CO}_{2}$ treatments with Ulva was significantly higher than elevated $\mathrm{CO}_{2}$ treatments without Ulva (Tukey HSD; $p=0.044$; Table S7). Furthermore, growth rates based on shell length showed strong significant positive correlations with $\Omega_{\text {aragonite }}$ and $\Omega_{\text {calcite }}$ across all treatments $\left(R^{2}=0.79, p<0.001\right.$ and $R^{2}=0.79, p<0.001$, respectively; Table S10). There were also significant correlations between growth based on shell weight and $\Omega_{\text {aragonite }}$ $\left(R^{2}=0.53, p=0.001\right.$; Table S10) and $\Omega_{\text {calcite }}\left(R^{2}=0.53\right.$, $p=0.002$; Table S11). For growth based on tissue weight,
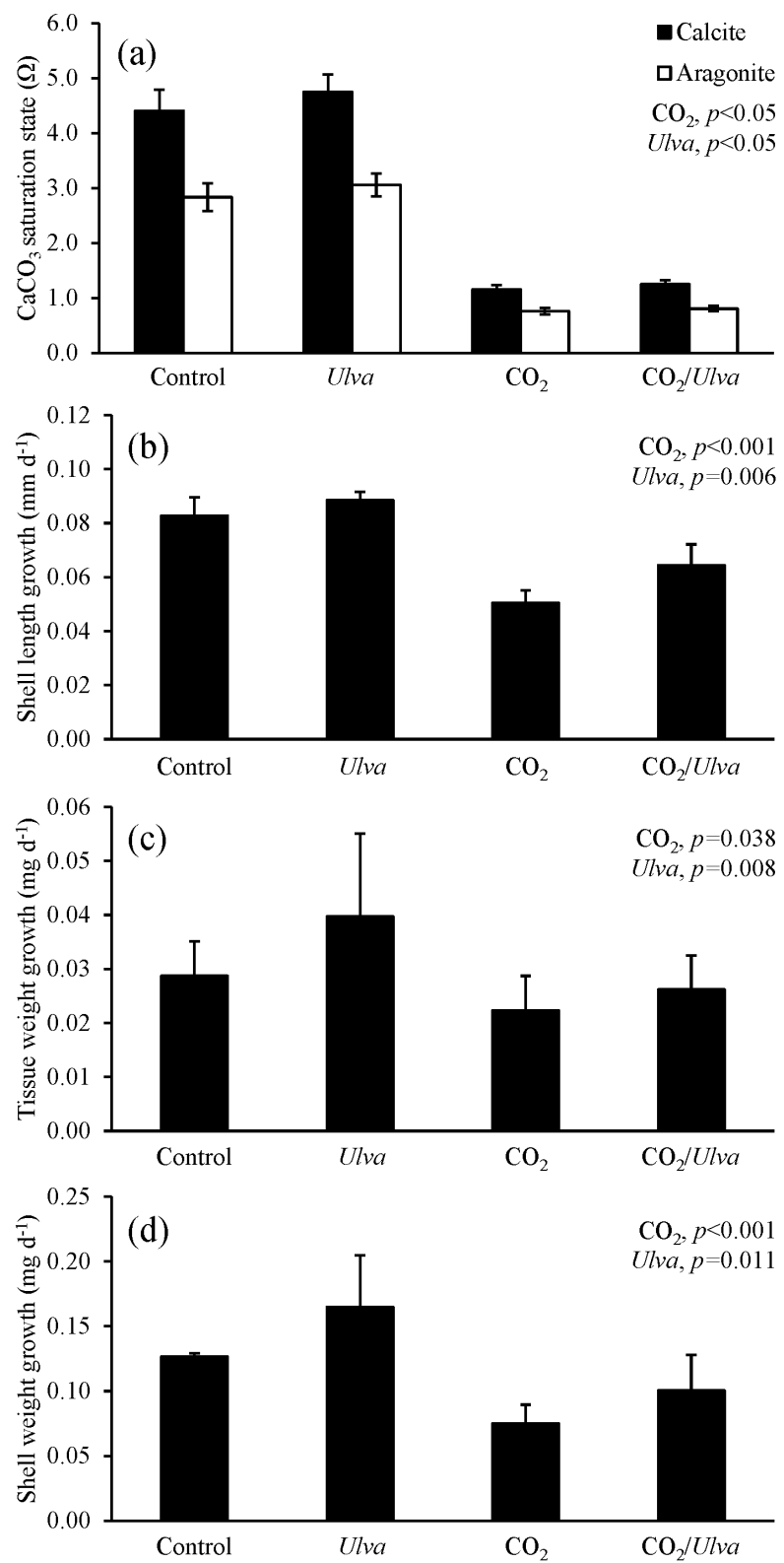

Figure 1. Experiment with small juvenile Mercenaria mercenaria exposed to ambient and elevated concentrations of $\mathrm{CO}_{2}$ with and without the presence of Ulva. (a) $\Omega_{\text {calcite }}$ and $\Omega_{\text {aragonite }}$; growth was based on (b) shell length, (c) tissue weight, and (d) shell weight. Columns represent means \pm standard deviation. Significant main treatment effects $\left(\mathrm{CO}_{2}\right.$ and $\left.U l v a\right)$ appear at the top right of each panel.

there were also significant correlations with $\Omega_{\text {aragonite }}$ and $\Omega_{\text {calcite }}\left(R^{2}=0.30, p=0.05\right.$ and $R^{2}=0.30, p=0.05$, respectively; Tables S10-S11).

For the larger-sized cohort of M. mercenaria (5.00 \pm $0.41 \mathrm{~mm}), \Omega_{\text {calcite }}$ and $\Omega_{\text {aragonite }}$ were significantly higher in treatments containing Ulva (two-way ANOVA; $p=0.002$ and $p<0.001$, respectively; Fig. 2; Tables S2-S3) and sig- 

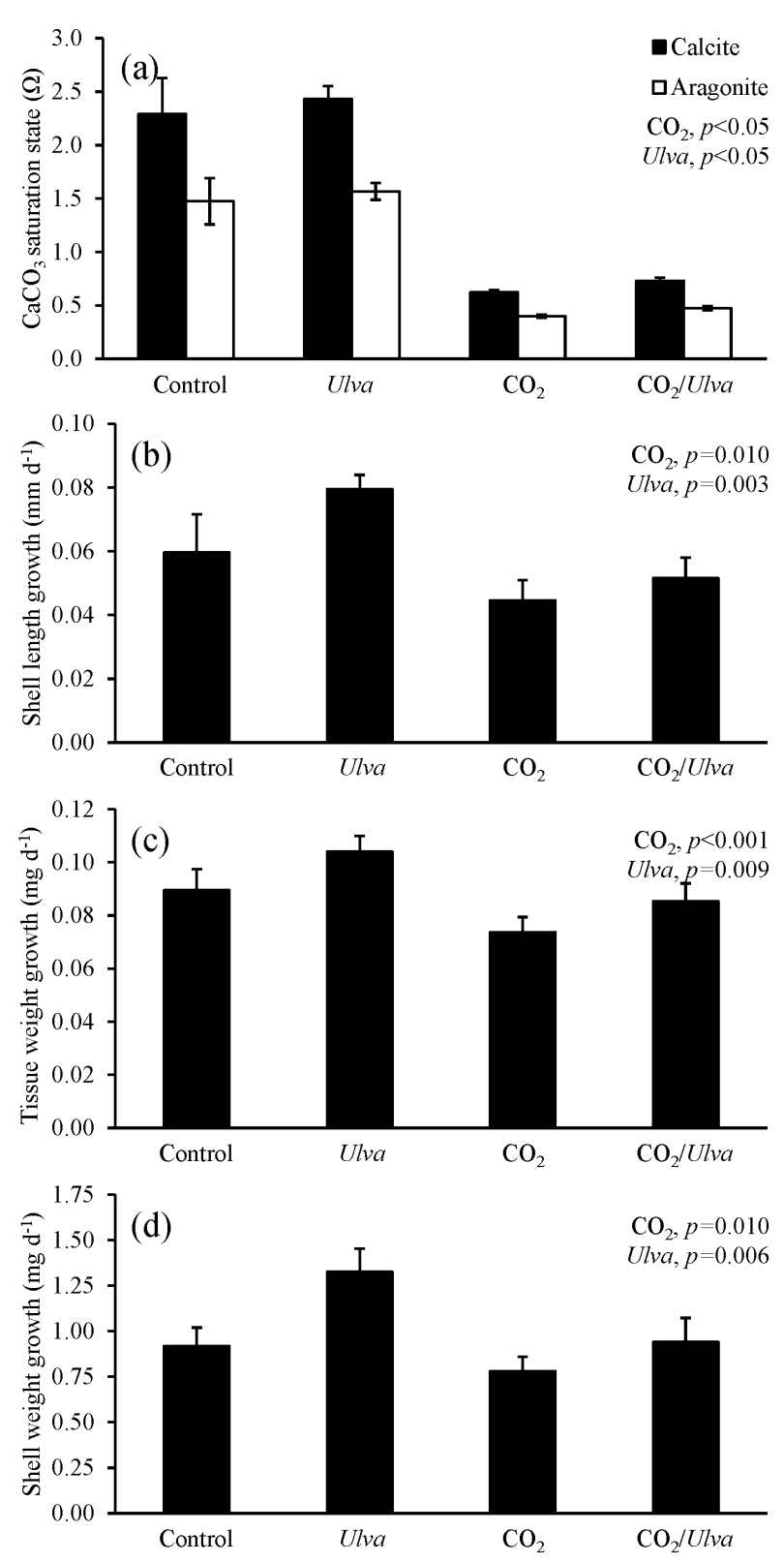

Figure 2. Experiment with large juvenile Mercenaria mercenaria exposed to ambient and elevated concentrations of $\mathrm{CO}_{2}$ with and without the presence of Ulva. (a) $\Omega_{\text {calcite }}$ and $\Omega_{\text {aragonite; }}$ growth was based on (b) shell length, (c) tissue weight, and (d) shell weight. Columns represent means \pm standard deviation. Significant main treatment effects $\left(\mathrm{CO}_{2}\right.$ and $\left.U l v a\right)$ appear at the top right of each panel.

nificantly lower in high- $\mathrm{CO}_{2}$ treatments (two-way ANOVA; $p<0.001$ for both). Larger M. mercenaria responded to elevated $\mathrm{CO}_{2}$ conditions and the presence of Ulva in a manner similar to that of the smaller clams. Under elevated $\mathrm{CO}_{2}$ concentrations, growth rates based on shell length, shell weight, and tissue weight were significantly lower (by $45 \%, 30 \%$, and $22 \%$, respectively) than the ambient $\mathrm{CO}_{2}$ treatments (two-way ANOVA; $p=0.010, p=0.010$, and $p<0.001$, respectively; Fig. 2; Tables S4-S6). In the presence of Ulva; however, growth rates based on shell length, shell weight, and tissue weight were significantly higher by $10 \%, 21 \%$, and $20 \%$, respectively, in elevated $\mathrm{CO}_{2}$ treatments and by $21 \%, 18 \%$, and $162 \%$, respectively, in ambient $\mathrm{CO}_{2}$ treatments that did not receive Ulva (two-way ANOVA; $p=$ $0.003, p=0.006$, and $p=0.009$, respectively; Fig. 2; Tables S4-S6). Across all treatments, growth rates based on shell length and tissue weight were positively correlated with $\Omega_{\text {aragonite }}\left(R^{2}=0.45, p=0.006\right.$ and $R^{2}=0.44, p=0.013$, respectively; Table S10) and $\Omega_{\text {calcite }}\left(R^{2}=0.45, p=0.006\right.$ and $R^{2}=0.44, p=0.013$, respectively; Table S11). For growth based on shell weight, there were positive, nearly significant correlations with $\Omega_{\text {aragonite }}$ and $\Omega_{\text {calcite }}\left(R^{2}=\right.$ $0.28, p=0.063$ and $R^{2}=0.28, p=0.063$, respectively; Tables S10-S11).

\subsection{Crassostrea virginica}

During the experiment with the cohort of small $C$. virginica $(2.45 \pm 0.41 \mathrm{~mm}), \Omega_{\text {calcite }}$ and $\Omega_{\text {aragonite }}$ were significantly higher in treatments containing Ulva (two-way ANOVA; $p=$ 0.025 for both; Fig. 3; Tables S2-S3) and significantly lower in treatments receiving elevated $\mathrm{CO}_{2}$ (two-way ANOVA; $p<0.001$ for both). Growth rates of small C. virginica were sensitive to elevated $\mathrm{CO}_{2}$ concentrations and the presence of Ulva. Growth rates based on length, tissue, and shell weight were $63 \%, 78 \%$, and $145 \%$ lower, respectively, when exposed to elevated $\mathrm{CO}_{2}$ concentrations compared to control treatments (two-way ANOVA; $p=0.011, p=0.006$, and $p=0.012$, respectively; Fig. 3; Tables S4-S6). When in the presence of Ulva, growth based on shell length was significantly increased by $24 \%$ and $55 \%$ in elevated and ambient $\mathrm{CO}_{2}$ treatments, respectively (two-way ANOVA; $p=$ 0.040; Fig. 3; Table S4), but growth based on tissue and shell weight was not significantly different than the control (two-way ANOVA; $p=0.319$ and $p=0.946$, respectively). Across all experimental vessels, there were significant positive correlations between growth based on shell length, tissue weight, and shell weight and $\Omega_{\text {aragonite }}\left(R^{2}=0.26, p=\right.$ $0.044 ; R^{2}=0.53, p=0.003$; and $R^{2}=0.39, p=0.013$, respectively; Table S10) and $\Omega_{\text {calcite }}\left(R^{2}=0.26, p=0.045\right.$; $R^{2}=0.53, p=0.003$; and $R^{2}=0.39, p=0.013$, respectively; Table S11).

For the larger juvenile $C$. virginica $(24.92 \pm 0.89 \mathrm{~mm})$, $\Omega_{\text {calcite }}$ and $\Omega_{\text {aragonite }}$ were significantly higher in treatments containing Ulva (two-way ANOVA; $p<0.001$ for both; Fig. 4; Tables S2-S3) and significantly lower in treatments receiving elevated $\mathrm{CO}_{2}$ (two-way ANOVA; $p<0.001$ for both). Growth responses for the larger $C$. virginica differed from the smaller-sized juveniles. Growth based on shell length was $167 \%$ significantly lower under elevated $\mathrm{CO}_{2}$ concentrations relative to the control and significantly higher (by $23 \%$ and $450 \%$ in ambient and elevated $\mathrm{CO}_{2}$ treatments, 

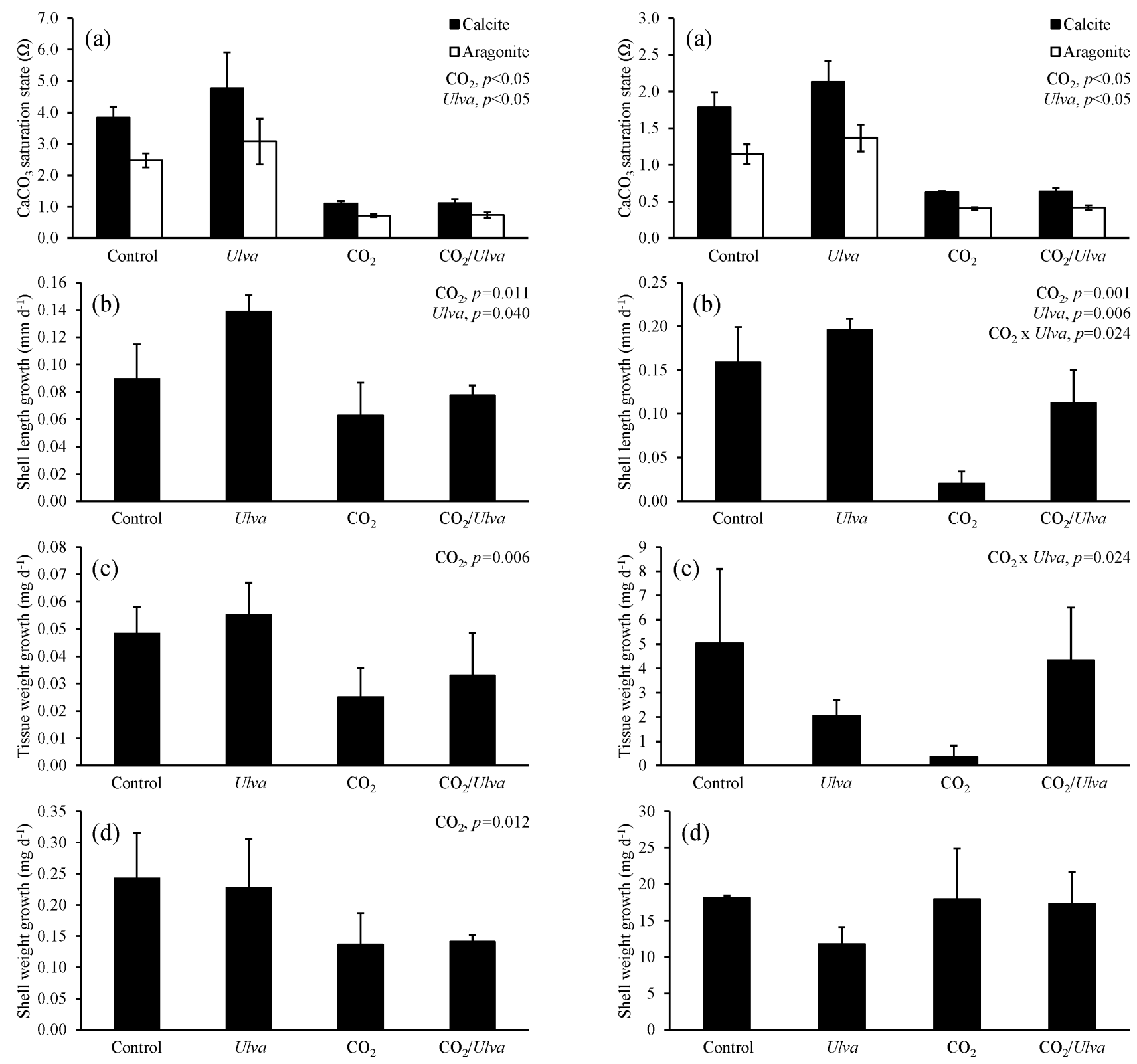

Figure 3. Experiment with small juvenile Crassostrea virginica exposed to ambient and elevated concentrations of $\mathrm{CO}_{2}$ with and without the presence of Ulva. (a) $\Omega_{\text {calcite }}$ and $\Omega_{\text {aragonite; }}$ growth was based on (b) shell length, (c) tissue weight, and (d) shell weight. Columns represent means \pm standard deviation. Significant main treatment effects $\left(\mathrm{CO}_{2}\right.$ and $\left.U l v a\right)$ appear at the top right of each panel.

respectively) in the presence of Ulva relative to the control (two-way ANOVA; $p=0.001$ and $p=0.006$, respectively; Fig. 4; Table S4). While growth based on shell weight and tissue weight was not significantly altered by elevated $\mathrm{CO}_{2}$ or the presence of Ulva, there was an antagonistic, interactive effect between both variables whereby the co-exposure to elevated $\mathrm{CO}_{2}$ and Ulva yielded growth rates higher than

Figure 4. Experiment with large juvenile Crassostrea virginica exposed to ambient and elevated concentrations of $\mathrm{CO}_{2}$ with and without the presence of Ulva. (a) $\Omega_{\text {calcite }}$ and $\Omega_{\text {aragonite }}$; growth was based on (b) shell length, (c) tissue weight, and (d) shell weight. Columns represent means \pm standard deviation. Significant main treatment effects $\left(\mathrm{CO}_{2}\right.$ and $\left.U l v a\right)$ appear at the top right of each panel.

would have been predicted by growth rates within the individual treatments (two-way ANOVA; $p=0.024$; Fig. 4; Tables S5-S6). Consistent with this finding, growth based on shell length in elevated $\mathrm{CO}_{2}$ treatments with Ulva was significantly higher than in elevated $\mathrm{CO}_{2}$ treatments without Ulva (Tukey HSD; $p=0.032$; Table S7). There was a strong positive correlation between growth based on shell length and 

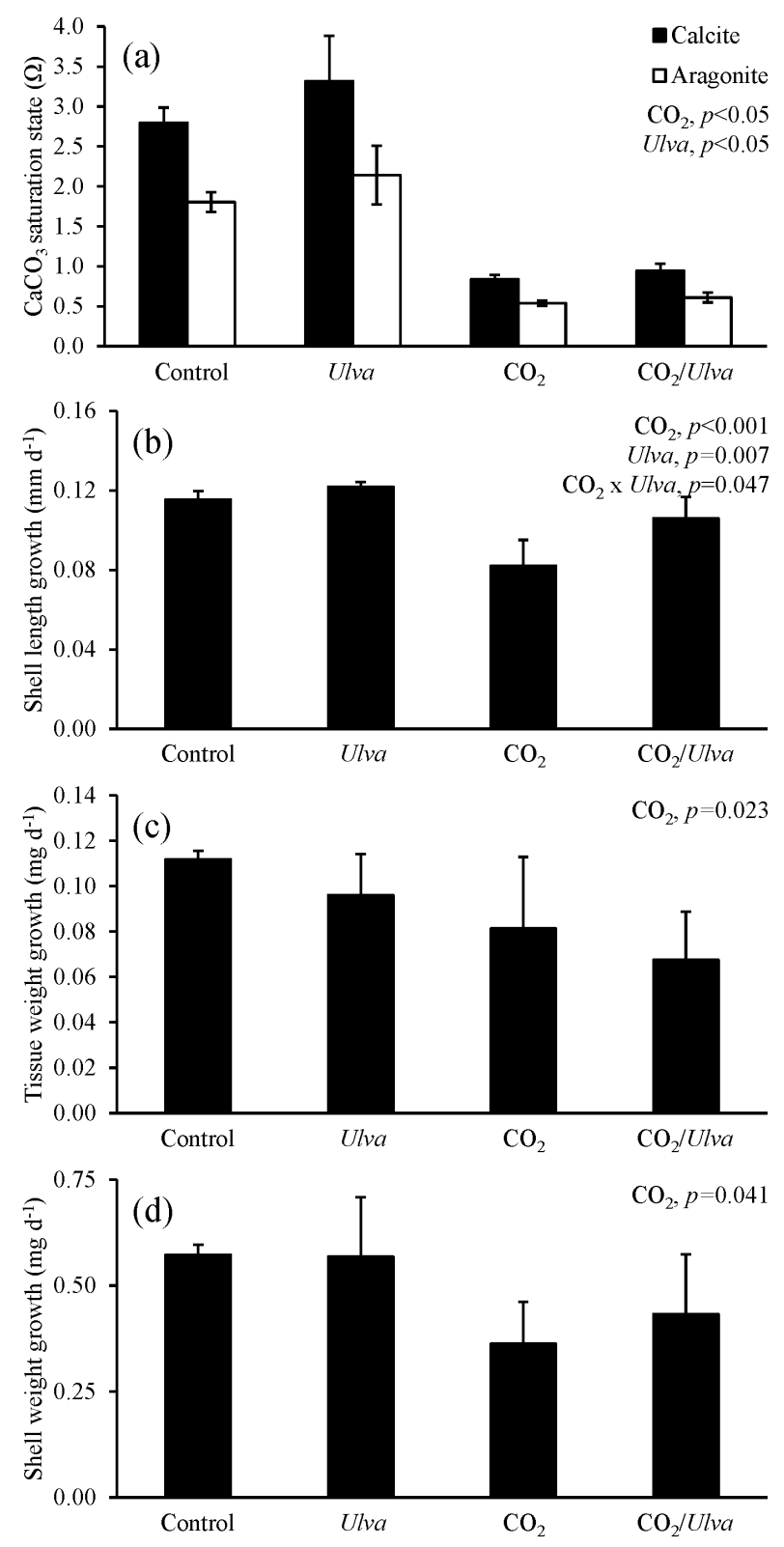

Figure 5. Experiment with small juvenile Argopecten irradians exposed to ambient and elevated concentrations of $\mathrm{CO}_{2}$ with and without the presence of Ulva. (a) $\Omega_{\text {calcite }}$ and $\Omega_{\text {aragonite; }}$ growth was based on (b) shell length, (c) tissue weight, and (d) shell weight. Columns represent means \pm standard deviation. Significant main treatment effects $\left(\mathrm{CO}_{2}\right.$ and Ulva $)$ appear at the top right of each panel.

$\Omega_{\text {aragonite }}\left(R^{2}=0.66, p=0.002\right.$, respectively; Table $\left.\mathrm{S} 10\right)$ and $\Omega_{\text {calcite }}\left(R^{2}=0.66, p=0.002\right.$, respectively; Table S11) but not for growth based on tissue and shell weight.

\subsection{Argopecten irradians}

For the cohort of small $A$. irradians $(4.73 \pm 0.59 \mathrm{~mm}), \Omega_{\text {calcite }}$ and $\Omega_{\text {aragonite were significantly higher in treatments contain- }}$ ing Ulva (two-way ANOVA; $p<0.001$ for both; Fig. 5; Tables S2-S3) and significantly lower in treatments with elevated $\mathrm{CO}_{2}$ (two-way ANOVA; $p<0.001$ for both). The growth of small juvenile $A$. irradians was altered by $p \mathrm{CO}_{2}$ and, to a lesser extent, the presence of Ulva. Growth rates based on shell length, tissue weight, and shell weight were significantly reduced by exposure to elevated $\mathrm{CO}_{2}$ concentrations (two-way ANOVA; $p<0.001, p=0.023$, and $p=0.041$, respectively; Fig. 5; Tables S4-S6). Specifically, growth rates based on shell length, tissue weight, and shell weight were $26 \%, 40 \%$, and $43 \%$ lower, respectively, when exposed to elevated $\mathrm{CO}_{2}$ compared to ambient $\mathrm{CO}_{2}$ treatments (Fig. 5). Growth based on shell length was significantly higher (by $10 \%$ and $29 \%$ in ambient and elevated $\mathrm{CO}_{2}$ treatments, respectively) in the presence of Ulva relative to treatments that did not receive Ulva (two-way ANOVA; $p=0.007$; Fig. 5; Table S4). In contrast, growth based on tissue and shell weight was not significantly affected by the presence of Ulva (two-way ANOVA; $p=0.274$ and $p=$ 0.637, respectively; Fig. 5; Tables S5-S6). Growth based on shell length within elevated $\mathrm{CO}_{2}$ treatments with Ulva was significantly higher than in the elevated $\mathrm{CO}_{2}$ treatments without Ulva (Tukey HSD; $p=0.011$; Table S7). There were no significant differences in growth based on shell or tissue weight among any treatments (Tukey HSD; $p>0.05$ for all; Tables S8-S9). Comparisons within individual treatments showed that growth based on shell length within elevated $\mathrm{CO}_{2}$ treatments without Ulva was significantly lower than the elevated $\mathrm{CO}_{2}$ treatments with Ulva (Tukey HSD; $p=0.011$; Table S7). For all treatments, there were significant correlations among growth based on shell length, tissue weight, and shell weight of smaller scallops and $\Omega_{\text {aragonite }}$ $\left(R^{2}=0.56, p=0.001 ; R^{2}=0.36, p=0.018\right.$; and $R^{2}=$ $0.47, p=0.004$, respectively; Table S10) and $\Omega_{\text {calcite }}\left(R^{2}=\right.$ $0.56, p=0.001 ; R^{2}=0.36, p=0.018 ;$ and $R^{2}=0.47, p=$ 0.004 , respectively; Table S11).

For the larger cohorts of juvenile A. irradians $(21.08 \pm$ $1.06 \mathrm{~mm}), \Omega_{\text {calcite }}$ and $\Omega_{\text {aragonite }}$ were significantly lower in treatments exposed to high $\mathrm{CO}_{2}$ and significantly higher in treatments containing Ulva (two-way ANOVA; $p<0.001$ for all; Fig. 6; Tables S2-S3). The growth rates of larger A. irradians based on shell length and tissue weight were significantly reduced under elevated $\mathrm{CO}_{2}$ concentrations by $32 \%$ and $105 \%$, respectively (two-way ANOVA; $p<0.001$ and $p=0.019$, respectively; Fig. 6; Tables S4 and S6) while growth based on shell weight was not (two-way ANOVA; $p=0.553$; Table S5). Growth rates based on shell length and tissue weight were significantly increased in the presence of Ulva by $16 \%$ and $16 \%$, respectively, in elevated $\mathrm{CO}_{2}$ treatments, and by $60 \%$ and $16 \%$, respectively, in ambient $\mathrm{CO}_{2}$ treatments (two-way ANOVA; $p=0.016$ and $p=$ 

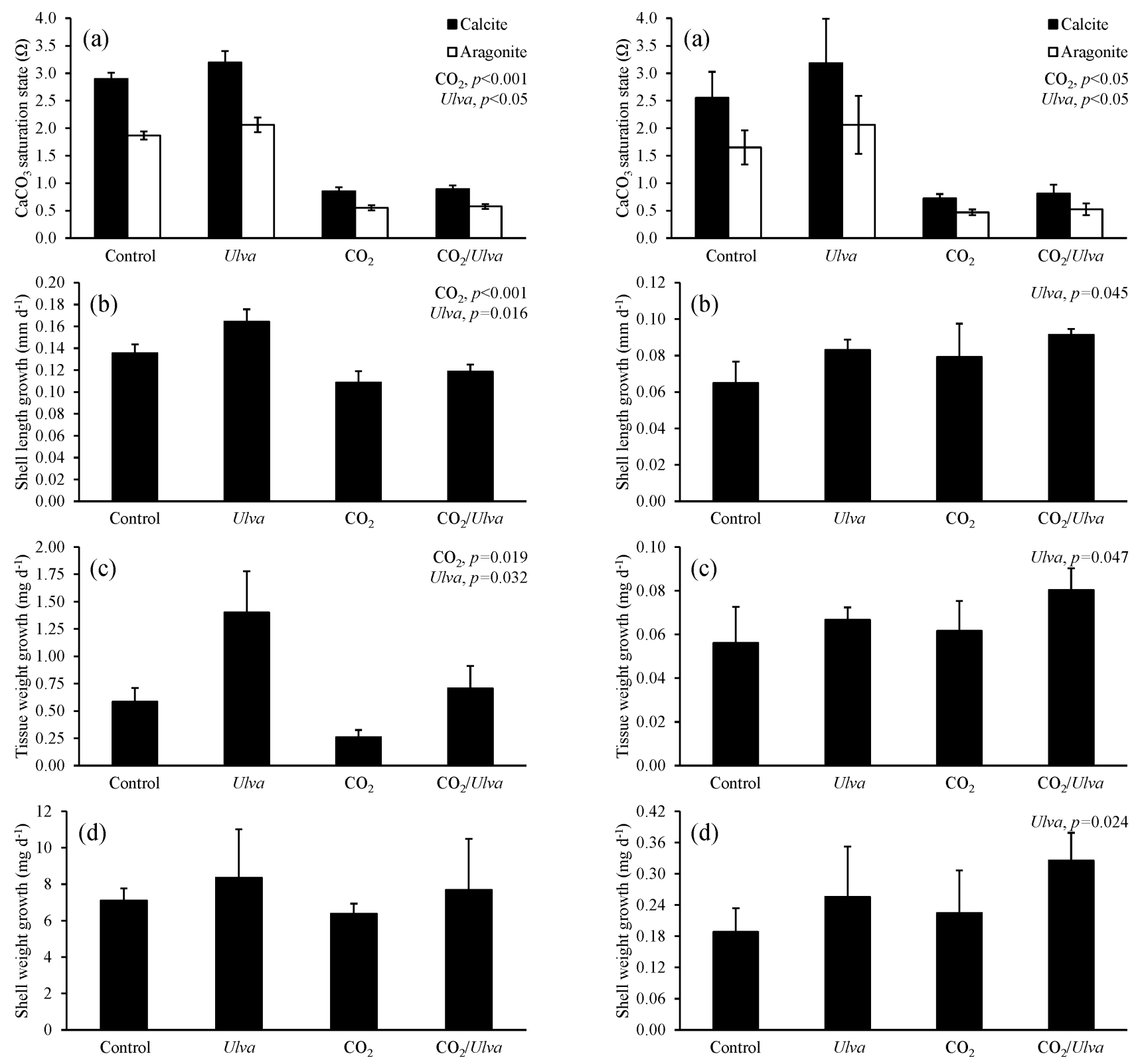

Figure 6. Experiment with large Argopecten irradians exposed to ambient and elevated concentrations of $\mathrm{CO}_{2}$ with and without the presence of Ulva. (a) $\Omega_{\text {calcite }}$ and $\Omega_{\text {aragonite }}$; growth was based on (b) shell length, (c) tissue weight, and (d) shell weight. Columns represent means \pm standard deviation. Significant main treatment effects $\left(\mathrm{CO}_{2}\right.$ and Ulva $)$ appear at the top right of each panel.

0.032, respectively; Fig. 6; Tables S4 and S6) while growth based on shell weight was not (two-way ANOVA; $p=0.390$; Table S5). There was a strong positive correlation among growth based on shell length of larger scallops and $\Omega_{\text {aragonite }}$ $\left(R^{2}=0.74 ; p=0.001\right.$, respectively; Table S10) and $\Omega_{\text {calcite }}$ $\left(R^{2}=0.74 ; p=0.001\right.$, respectively; Table S11) but not for growth based on tissue and shell weight.

Figure 7. Experiment with Mytilus edulis exposed to ambient and elevated concentrations of $\mathrm{CO}_{2}$ with and without the presence of Ulva. (a) $\Omega_{\text {calcite }}$ and $\Omega_{\text {aragonite; }}$ growth was based on (b) shell length, (c) tissue weight, and (d) shell weight. Columns represent means \pm standard deviation. Significant main treatment effects $\left(\mathrm{CO}_{2}\right.$ and Ulva) appear at the top right of each panel.

\subsection{Mytilus edulis}

During the experiments with $M$. edulis $(4.87 \pm 0.92 \mathrm{~mm})$, $\Omega_{\text {calcite }}$ and $\Omega_{\text {aragonite }}$ were significantly higher in treatments containing Ulva (two-way ANOVA; $p=0.017$ and $p=$ 0.020 , respectively; Fig. 7; Tables $\mathrm{S} 2-\mathrm{S} 3$ ) and significantly lower in treatments exposed to high $\mathrm{CO}_{2}$ (two-way ANOVA; $p<0.001$ for both). Growth rates of M. edulis based on shell 
length, tissue weight, and shell weight were all not significantly changed by exposure to elevated $\mathrm{CO}_{2}$ concentrations (two-way ANOVA; $p=0.149, p=0.210$, and $p=0.439$, respectively; Fig. 7; Tables S4-S6). In contrast, growth measurements based on shell length, tissue weight, and shell weight were significantly higher in the presence of Ulva (two-way ANOVA; $p=0.045, p=0.047$, and $p=0.024$, respectively; Fig. 7; Tables S4-S6). Specifically, in the presence of Ulva, growth based on shell length, tissue weight, and shell weight was $16 \%, 30 \%$, and $45 \%$ higher, respectively, in elevated $\mathrm{CO}_{2}$ treatments and $28 \%, 19 \%$, and $36 \%$, respectively, in ambient $\mathrm{CO}_{2}$ treatments relative to treatments that did not receive Ulva (Fig. 7). Mussel growth rates were not correlated with $\Omega_{\text {aragonite }}$ or $\Omega_{\text {calcite }}$ (Tables S10-S11).

\subsection{Ulva and microalgae}

Across all experiments, the growth of Ulva was found to be significantly higher by $20 \%$ when exposed to elevated $\mathrm{CO}_{2}$ concentrations (one-way ANOVA; $p=0.043$; Fig. S1; Table S12). Concentrations of Isochrysis galbana and Chaetoceros muelleri were not significantly different among any treatments in any experiments (two-way ANOVA; $p<$ 0.05 for all; Table S12). On average, final cell concentrations within treatments were $\sim 90000$ cells mL ${ }^{-1}$ (Tables 1 and S1).

\section{Discussion}

During this study, elevated $\mathrm{CO}_{2}$ concentrations significantly reduced at least one or more growth measurements of cohorts of small- and large-sized juvenile Mercenaria mercenaria, Crassostrea virginica, and Argopecten irradians, but not Mytilus edulis. The presence of Ulva significantly increased the growth of all cohorts of all bivalve species. Comparisons of individual treatments indicated that under elevated $\mathrm{CO}_{2}$ concentrations, the addition of Ulva often significantly increased growth rates of clams, scallops, and oysters by $23 \%-30 \%$. Both $\Omega_{\text {aragonite }}$ and $\Omega_{\text {calcite }}$ were significantly higher in the presence of Ulva in all experiments under both high- and low- $\mathrm{CO}_{2}$ regimes, despite the rapid turnover of dissolved gas pools in experiments ( $>1000$ time per day), and the growth rates of bivalves were significantly correlated with $\Omega_{\text {aragonite }}$ and $\Omega_{\text {calcite }}$ in treatment vessels for six of seven experiments. Collectively, these findings provide insight regarding the ability of macroalgae such as Ulva to mitigate the deleterious effects of ocean acidification on bivalves and, potentially, other calcifying organisms.

The negative effects of ocean acidification on the growth and survival of bivalves and other calcifying organisms have been well documented. Consistent with prior studies that have gauged the response of juvenile bivalves to elevated $\mathrm{CO}_{2}$ (Gazeau et al., 2007; Green et al., 2009; Talmage and Gobler, 2011), the results of the current study show de- creased tissue growth as well as calcification in the form of growth based on shell length and weight under acidified conditions, a finding consistent with significantly lower $\Omega_{\text {aragonite }}$ and $\Omega_{\text {calcite }}$ in elevated $\mathrm{CO}_{2}$ treatments. Earlylife-stage bivalve shells are composed partly or completely of aragonite, making them vulnerable to undersaturation of aragonite (Carriker, 1996; Stenzel, 1964; Talmage and Gobler, 2009). While the formation of calcium carbonate is thermodynamically favored when $\Omega$ exceeds 1.0 , biotic aragonite is less crystalline than nonbiogenic aragonite (Weiss et al., 2002) and studies of early-life-stage Pacific oysters have suggested that a $\Omega_{\text {aragonite }}$ exceeding 1.6 may be required to yield successful growth and survival (Barton et al., 2012). Similarly, Talmage and Gobler (2010) found that increases in $\Omega_{\text {aragonite }}$ within the saturated range $\left(\Omega_{\text {aragonite }}\right.$ increases from 2.9 to 3.3) significantly increased the growth of earlylife-stage M. mercenaria and A. irradians, a finding suggesting that acidification since preindustrial times can depress the performance of these species. In the current study, growth rates of bivalves exposed to Ulva under ambient $p \mathrm{CO}_{2}$ frequently exceeded those of individuals grown under the same $\mathrm{CO}_{2}$ delivery rate without $U l v a$ as $\Omega_{\text {aragonite }}$ was significantly increased, on average from 1.91 to 2.16 (Table 1), with both levels being saturated but also being below the threshold that yielded maximal growth rates in early-life-stage bivalves for Talmage and Gobler (2010). Furthermore, even minor, yet sustained, increases or decreases in $\Omega_{\text {aragonite }}(<0.1$ units) can result in significant changes in the growth of larval and juvenile bivalves (Barton et al., 2012; Talmage and Gobler, 2011), which was similarly observed in many of the experiments in the present study. Hence, the potential benefits of macroalgae to calcifying bivalves may be realized in both acidified and normal conditions.

Acidification can have cascading negative physiological consequences for bivalves. In larval bivalves, high $\mathrm{CO}_{2}$ depresses calcification, lipid content, RNA : DNA ratios, metamorphosis, and growth rates (Gobler and Talmage, 2013). The reduction in growth based on tissue weight under elevated $\mathrm{CO}_{2}$ concentrations found during the present study is consistent with Beniash et al. (2010), who found significant declines in soft body mass of juvenile $C$. virginica maintained in hypercapnia ( $\mathrm{pH} 7.5$ ). Additionally, the same study and others (Gazeau et al., 2007; Matoo et al., 2013) have reported increased metabolic rates in bivalves exposed to elevated $\mathrm{CO}_{2}$ levels. As suggested by Waldbusser et al. (2015b), decreasing $\Omega_{\text {aragonite }}$ increases the amount of energy spent by bivalves on shell formation, which diverts energy away from maintaining homeostasis and other metabolic processes including those that contribute toward growth (Beniash et al., 2010; Waldbusser et al., 2015b).

Macroalgae can control carbonate chemistry in shallow ecosystems and, in turn, can affect the performance of carbonaceous organisms. A study by Anthony et al. (2013) found that within mixed assemblages of turf and fleshy macroalgae, the saturation state of aragonite increased dur- 
ing the daytime. Krause-Jensen et al. (2015) reported that macroalgae may provide a refuge for calcifying organisms. Specifically, within a subarctic fjord, macroalgae drove strong diel variability in $\mathrm{pH}$ and $\Omega_{\text {aragonite, }}$ with $M$. edulis being found to grow in close association with macroalgae, even in tidal pools that became supersaturated and undersaturated between day and night cycles, respectively (KrauseJensen et al., 2015). Additionally, Wahl et al. (2017) demonstrated that daytime increases in $\mathrm{pH}$ associated with the macroalgae Fucus vesiculosus provided a refuge against acidified conditions for M. edulis, with calcification rates of M. edulis increasing with increases in $\mathrm{pH}$ wrought by the algae. In the current study, Ulva yielded significantly increased $\Omega_{\text {aragonite }}, \Omega_{\text {calcite, }}$, and bivalve growth in all seven experiments performed. Dissolved oxygen levels were also high (> $8 \mathrm{mg} \mathrm{L}^{-1}$ ) in all treatments and the growth rates of bivalves were often significantly higher in high- $\mathrm{CO}_{2}$ treatments with Ulva compared to those without. Furthermore, in ambient and elevated $\mathrm{CO}_{2}$ treatments, the presence of Ulva significantly increased $\mathrm{pH}$ beyond levels observed in treatments without Ulva, often in as little as $24 \mathrm{~h}$, with those increases sustained over the duration of the experiments (Figs. S2-S3). Hence, it seems likely that the macroalgae buffered carbonate chemistry to the benefit of bivalves. While it is possible that photosynthetic activity by microalgae (I. galbana and $C$. muelleri) may have contributed to shifts in carbonate chemistry, there were no significant differences in microalgae cell concentrations in any treatment across all experiments (two-way ANOVA; $p>0.05$; Table S13), suggesting that microalgal contributions to changes in carbonate chemistry were minimal relative to the photosynthetic activity of Ulva.

Beyond photosynthesis, macroalgae may also alter carbonate chemistry via the uptake of nitrogenous nutrients. Specifically, the uptake of nitrate or ammonium by marine autotrophs results in an equimolar increase or decrease in total alkalinity, respectively (Brewer and Goldman, 1976; Goldman and Brewer, 1980; Talmage and Gobler, 2012), which occurs due to the production of $\mathrm{OH}^{-}$and $\mathrm{H}^{+}$to balance the uptake of nitrate and ammonium, respectively (Brewer and Goldman, 1976; Goldman and Brewer, 1980; Redfield et al., 1963). Given that $50 \mu \mathrm{M}$ of nitrate was added to all experimental vessels with Ulva to promote its growth during each experimental water change, it is possible that the assimilation of this nitrate by Ulva contributed to the average $10-20 \mu \mathrm{M}$ increase in total alkalinity observed within treatments with Ulva (two-way ANOVA; $p<0.05$; Table 1; Tables S14-S15). Higher-alkalinity seawater requires higher concentrations of $\mathrm{CO}_{2}$ to reduce $\mathrm{pH}$, thus resulting in smaller changes in $\Omega_{\text {aragonite }}$ and $\Omega_{\text {calcite. Given the rapid turnover of }}$ dissolved gasses in experimental vessels, it is possible the nitrogen assimilation effects on alkalinity outweighed the effects of photosynthetic consumption of DIC.

Prior studies have found that Ulva can experience enhanced growth (Björk et al., 1993; Olischläger et al., 2013;
Young and Gobler, 2016) and outcompete other autotrophs (Young and Gobler, 2017) under elevated $\mathrm{CO}_{2}$ concentrations. Hence, the dominance of Ulva and similar macroalgae in estuaries that experience seasonal acidification (Wallace and Gobler, 2015) could ultimately benefit bivalves and other calcifying organisms. In the present experiments, Ulva growth was, on average, $\sim 20 \%$ higher under elevated $\mathrm{CO}_{2}$ conditions. Furthermore, the presence of the macroalgae frequently transformed $\Omega_{\text {aragonite }}$ of elevated $\mathrm{CO}_{2}$ treatments from undersaturated to nearly saturated (Tables 1 and S1) and often yielded growth rates of bivalves significantly greater than the elevated $\mathrm{CO}_{2}$ treatments without Ulva. Had the dissolved gas pools within experimental vessels not been turned over rapidly via aeration, it is possible the effects of Ulva on the carbonate chemistry would have been even greater.

The benefits of Ulva and detriments of high $\mathrm{CO}_{2}$ to the four bivalves studied differed by species. While every cohort displayed significantly enhanced growth in the presence of Ulva, scallops were the only species to experience significantly higher growth in the elevated $\mathrm{CO}_{2}$ treatment with Ulva compared to the elevated $\mathrm{CO}_{2}$ treatment without Ulva for both the small and large juvenile cohorts. In contrast, for clams and oysters, only one of the two cohorts displayed this specific response. Early life stages of bay scallops have been consistently shown to be more vulnerable to acidification than the other bivalve species studied here (Stevens and Gobler, 2018; Talmage and Gobler, 2009, 2011). This may be due, in part, to its rapid growth and metabolism compared to other bivalves (Kennedy et al., 1996; Kraeuter and Castagna, 2001; Shumway and Parsons, 2006), traits that may also make it more likely to benefit from the improved carbonate chemistry wrought by the presence of Ulva. The resistance of $M$. edulis to elevated $\mathrm{CO}_{2}$ concentrations contrasted with prior studies of European strains of this bivalve (Berge et al., 2006; Gazeau et al., 2007) but is consistent with prior cohorts of this species isolated from Shinnecock Bay, NY, USA (Stevens and Gobler, 2018). However, Thomsen et al. (2013) found that specific growth and calcification rates of juvenile $M$. edulis under acidified conditions were dependent on food availability. Given that food was supplied ad libitum in the present study, it is possible that the negative effects of elevated $\mathrm{CO}_{2}$ concentrations on M. edulis may have been mitigated by adequate food availability as well as improved carbonate chemistry facilitated by Ulva.

While growth rates of bivalves were significantly correlated with $\Omega_{\text {aragonite }}$ and $\Omega_{\text {calcite }}$ during this study, the absolute change in bivalve growth was greater than what might be expected from the observed Ulva-induced changes in $\Omega_{\text {aragonite }}$ and $\Omega_{\text {calcite }}$, suggesting other factors may have contributed to the increased growth of bivalves in treatments with Ulva. While Ulva increased dissolved oxygen levels in vessels, dissolved oxygen concentrations were high in all treatments $\left(>8 \mathrm{mg} \mathrm{L}^{-1}\right)$. Adequate food availability makes bivalves more resilient against ocean acidification (Thomsen et al., 2013), but microalgal food levels were always in ex- 
cess and did not differ across treatments in our experiments (Table S13). While we cannot discount the possibility that Ulva supplied an unknown nutritional factor that benefited the growth of the bivalves, this does not seem likely given the known particle capture range of juvenile bivalves $(\sim 3-$ $100 \mu \mathrm{m}$; Ward and Shumway, 2004). A more important factor to consider is the time of day during which discrete $\mathrm{pH}$ measurements were made during this study. Limited, continuous measurements of $\mathrm{pH}$ in vessels with Ulva made during this study revealed a strong diurnal pattern for $\mathrm{pH}$ values driven by photosynthesis, with minimal levels in the early morning and peak values in the evening (Fig. S4). The discrete, daily measurements of $\mathrm{pH}$ made in vessels that were used to determine the carbonate chemistry during this study were made during the late morning when $\mathrm{pH}$ values were low relative to the complete daily cycle (Fig. S4). Had our carbonate chemistry determinations been based on maximal $\mathrm{pH}$ values present during the late evening, we estimate that $\Omega_{\text {aragonite }}$ and $\Omega_{\text {calcite }}$ values would have been $\sim 0.4$ and $\sim 0.6$ units higher, respectively, than reported (Tables S1 and Fig. S4). Future studies that make continuous measurements of $\mathrm{pH}$ and DIC or measurements that represent the mean conditions present within vessels will be able to better represent the precise carbonate chemistry conditions that Ulva creates that, in turn, promote the growth of bivalves. Regardless, even with $\Omega_{\text {aragonite }}$ and $\Omega_{\text {calcite }}$ values that were likely underestimated, this study demonstrated the ability of Ulva to significantly increase $\Omega_{\text {aragonite }}, \Omega_{\text {calcite }}$, and bivalve growth rates as well as the significant correlation between $\Omega$ and bivalve growth rates.

Beyond the modification of carbonate chemistry, there are additional ecosystem benefits that may be provided by macroalgae. Macroalgal beds can serve as a nursery habitat for juvenile Callinectes sapidus (Wilson et al., 1990), as well as other decapods (Heck et al., 2003; Sogard and Able, 1991). Macroalgae can also serve as a refuge from predation for some juvenile and adult bivalves (Carroll et al., 2010). An additional potential benefit provided to bivalves by Ulva and other macroalgae is their ability to inhibit the growth of phytoplankton species that cause harmful algal blooms (HABs; Tang and Gobler, 2011; Tang et al., 2015) that can directly harm the bivalve species used in the present study (Gobler and Sunda, 2012; Leverone et al., 2006; Stoecker et al., 2008; Tang and Gobler, 2009). Furthermore, given its ability to rapidly assimilate and store nitrate and ammonium (Pedersen and Borum, 1997), Ulva can serve as a biofilter within eutrophic ecosystems (Hernández et al., 2002; Neori et al., 2003). Given that harmful algal blooms flourish in eutrophic zones (Anderson et al., 2008, 2002), the mitigation of high-nutrient conditions by Ulva may reduce the intensity of HABs, which may indirectly benefit bivalve species that are negatively impacted by the occurrence of such events. Finally, there is great precedent for the deployment of macroalgae as a principal component of integrated multi-trophic aquaculture systems whereby seaweeds are co- cultivated with aquacultured shellfish with the macroalgae often being harvested for profit (Neori, 2008; Nobre et al., 2010; Troell et al., 2009). Such an approach may be increasingly important for the protection of aquacultured bivalves in an increasing acidified ocean in the future.

Despite the reported positive interactions between Ulva and the various species of bivalves in prior studies (Carroll et al., 2010; Heck et al., 2003; Sogard and Able, 1991; Wilson et al., 1990; this study), macroalgae can negatively impact bivalves and other calcifying organisms. Secondary metabolites released by Ulva can elevate mortality rates in the larval stages of bivalves (Diederich, 2005; Nelson et al., 2003), barnacles (Brock et al., 2007; Magre, 1974), crabs (Johnson and Welsh, 1985), and molluscs (Wang et al., 2011). Ulva can form "green tides" (Smetacek and Zingone, 2013) that, upon their collapse, can create hypoxic regions (Valiela et al., 1992) that can negatively affect benthic fauna (Viaroli et al., 2001). Furthermore, extensive coverage of bivalves by Ulva and the subsequent decomposition of the algae can also result in the accumulation of $\mathrm{H}_{2} \mathrm{~S}$, which, when coupled with low dissolved oxygen, can depress the growth and survival of bivalves (Tyler, 2007). However, as pointed out by Wilson et al. (1990), the accumulation of secondary metabolites and decreased dissolved oxygen associated with the overgrowth of Ulva is often mitigated in high-flow areas, alleviating potential harm to the nearby organisms. Furthermore, it is likely that other macroalgae that are not known to negatively impact marine life provide similar buffering of carbonate chemistry (Anthony et al., 2013; Krause-Jensen et al., 2015; Wahl et al., 2017).

Numerous species of seagrass experience enhanced growth under elevated $\mathrm{CO}_{2}$ concentrations (Beer and Koch, 1996; Palacios and Zimmerman, 2007; Zimmerman et al., 1997) and can buffer ocean acidification, thus benefiting calcifying organisms (Garrard et al., 2014; Hendriks et al., 2014). However, this ecosystem service may be disrupted by eutrophication (Valiela et al., 1997) and acidification (Young et al., 2018) of coastal ecosystems, which could favor the growth of macroalgae over seagrass (Young et al., 2018). As seagrasses decline worldwide (Orth et al., 2006; Short et al., 2011), the ecosystem services provided by seagrasses, such as being nursery habitats or buffering against ocean acidification, may, in some cases, be provided by macroalgae, potentially benefiting calcifying organisms such as bivalves that had formerly depended on seagrass as a refuge habitat.

In conclusion, during this study photosynthetic activity and/or nitrate assimilation by Ulva increased $\Omega_{\text {aragonite }}$ and $\Omega_{\text {calcite }}$ and yielded enhanced growth of bivalves by mitigating the deleterious effects of elevated $p \mathrm{CO}_{2}$. This benefit was not exclusive to acidified conditions, as evidenced by increased bivalve growth in the presence of Ulva within ambient $\mathrm{CO}_{2}$ treatments. While macroalgae can have adverse effects on some larval-staged bivalves, the chemical resilience provided by the macroalgae Ulva, along with other potential ecosystem benefits such as providing nursery habitat (Wil- 
son et al., 1990) and predation refuge (Carroll et al., 2010) and inhibiting the growth of harmful microalgae (Tang and Gobler, 2011; Tang et al., 2015), may, in some cases, outweigh the negative effects. Given that macroalgae tend to outcompete seagrass under high- $\mathrm{CO}_{2}$ conditions (Young et al., 2018), the ability of macroalgae to provide ecosystem services similar to those of seagrass, particularly buffering carbonate chemistry, may be increasingly important for calcifying organisms in modern-day eutrophic acidified estuaries, as well as within future ocean acidification scenarios. Finally, the purposeful deployment of seaweeds in an aquaculture setting would seem to be a beneficial strategy for protecting bivalves against current and future acidification.

Data availability. There are no underlying data for the current study other than the Supplement.

Supplement. The supplement related to this article is available online at: https://doi.org/10.5194/bg-15-6167-2018-supplement.

Author contributions. CJG and CSY conceived and designed the experiments. CSY performed the experiments. CSY and CJG analyzed the data. CJG contributed reagents, materials, and analysis tools. CSY and CJG wrote the paper.

Competing interests. The authors declare that they have no conflict of interest.

Acknowledgements. We are grateful for the supply of Crassostrea virginica provided by the Cornell Cooperative Extension of Huntington, NY, and Southold, NY. We thank Stephen Heck for the collection of Mytilus edulis. We are appreciative of the logistical support provided by the Stony Brook Southampton Marine Science Center staff throughout this study. This work was supported by New York Sea grant R-FMB-38 and grants from the Chicago Community Foundation, the Laurie Landaeu Foundation, and the Pritchard Foundation.

Edited by: Clare Woulds

Reviewed by: three anonymous referees

\section{References}

Anderson, D. M., Glibert, P. M., and Burkholder, J. M.: Harmful algal blooms and eutrophication: Nutrient sources, composition, and consequences, Estuaries, 25, 704-726, https://doi.org/10.1007/BF02804901, 2002.

Anderson, D. M., Burkholder, J. M., Cochlan, W. P., Glibert, P. M., Gobler, C. J., Heil, C. A., Kudela, R. M., Parsons, M. L., Rensel, J. E. J., Townsend, D. W., Trainer, V. L., and Vargo, G. A.: Harmful algal blooms and eutrophication: Examining linkages from selected coastal regions of the United States, Harmful Algae, 8, 39-53, https://doi.org/10.1016/j.hal.2008.08.017, 2008.

Anthony, K. R. N., Diaz-Pulido, G., Verlinden, N., Tilbrook, B., and Andersson, A. J.: Benthic buffers and boosters of ocean acidification on coral reefs, Biogeosciences, 10, 4897-4909, https://doi.org/10.5194/bg-10-4897-2013, 2013.

Barton, A., Hales, B., Waldbusser, G. G., Langdon, C., and Feely, R. A.: The Pacific oyster, Crassostrea gigas, shows negative correlation to naturally elevated carbon dioxide levels: Implications for near-term ocean acidification effects, Limnol. Oceanogr., 57, 698-710, https://doi.org/10.4319/lo.2012.57.3.0698, 2012.

Baumann, H. and Smith, E. M.: Quantifying metabolically driven $\mathrm{pH}$ and oxygen fluctuations in US nearshore habitats at diel to interannual time scales, Estuar. Coast., 41, 1102-1117, https://doi.org/10.1007/s12237-017-0321-3, 2018.

Baumann, H., Wallace, R. B., Tagliaferri, T., and Gobler, C. J.: Large natural $\mathrm{pH}, \mathrm{CO}_{2}$ and $\mathrm{O}_{2}$ fluctuations in a temperate tidal salt marsh on diel, seasonal, and interannual time scales, Estuar. Coast., 38, 220-231, https://doi.org/10.1007/s12237-014-9800y, 2015.

Beer, S. and Koch, E.: Photosynthesis of marine macroalgae and seagrasses in globally changing $\mathrm{CO}_{2}$ environments, Mar. Ecol.Prog. Ser., 141, 199-204, https://doi.org/10.3354/meps141199, 1996.

Beniash, E., Ivanina, A., Lieb, N. S., Kurochkin, I., and Sokolova, I. M.: Elevated level of carbon dioxide affects metabolism and shell formation in oysters Crassostrea virginica, Mar. Ecol.-Prog. Ser., 419, 95-108, https://doi.org/10.3354/meps08841, 2010.

Berge, J. A., Bjerkeng, B., Pettersen, O., Schaanning, M. T., and Oxnevad, S.: Effects of increased sea water concentrations of $\mathrm{CO}_{2}$ on growth of the bivalve Mytilus edulis L, Chemosphere, 62, 681-687, https://doi.org/10.1016/j.chemosphere.2005.04.111, 2006.

Björk, M., Haglund, K., Ramazanov, Z., and Pedersén, M.: Inducible mechanisms for $\mathrm{HCO}_{3}^{-}$utilization and repression of photorespiration in protoplasts and thalli of three species of Ulva (Chlorophyta), J. Phycol., 29, 166-173, https://doi.org/10.1111/j.0022-3646.1993.00166.x, 1993.

Brewer, P. G. and Goldman, J. C.: Alkalinity changes generated by phytoplankton growth, Limnol. Oceanogr., 21, 108-117, https://doi.org/10.4319/lo.1976.21.1.0108, 1976.

Brock, E., Nylund, G. M., and Pavia, H.: Chemical inhibition of barnacle larval settlement by the brown alga Fucus vesiculosus, Mar. Ecol.-Prog. Ser., 337, 165-174, https://doi.org/10.3354/meps337165, 2007.

Cai, W.-J., Hu, X., Huang, W.-J., Murrell, M. C., Lehrter, J. C., Lohrenz, S. E., Chou, W.-C., Zhai, W., Hollibaugh, J. T., Wang, Y., Zhao, P., Guo, X., Gundersen, K., Dai, M., and Gong, G.-C.: Acidification of subsurface coastal waters enhanced by eutrophication, Nat. Geosci., 4, 766-770, https://doi.org/10.1038/ngeo1297, 2011.

Cai, W.-J., Huang, W.-J., Luther, G. W., Pierrot, D., Li, M., Testa, J., Xue, M., Joesoef, A., Mann, R., Brodeur, J., Xu, Y.-Y., Chen, B., Hussain, N., Waldbusser, G. G., Cornwell, J., and Kemp, W. M.: Redox reactions and weak buffering capacity lead to acidification in the Chesapeake Bay, Nat. Commun., 8, 369, https://doi.org/10.1038/s41467-017-00417-7, 2017.

Carriker, M. R.: The shell and ligment, in: The Eastern oyster: Crassostrea virginica, edited by: Kennedy, V. S., Newell, R. I. E., and 
Eble, A. E., Maryland Sea Grant College, University of Maryland System, 75-168, 1996.

Carroll, J. M., Peterson, B. J., Bonal, D., Weinstock, A., SMith, C. F., and Tettelbach, S. T.: Comparative survival of bay scallops in eelgrass and the introduced alga, Codium fragile, in a New York estuary, Mar. Biol., 157, 249-259, https://doi.org/10.1007/s00227-009-1312-0, 2010.

Dickson, A. G.: The measurement of sea water pH, Mar. Chem., 44, 131-142, https://doi.org/10.1016/0304-4203(93)90198-W, 1993.

Dickson, A. G., Sabine, C. L., and Christian, J. R.: Guide to best practices for ocean $\mathrm{CO}_{2}$ measurements, PICES Special Publication, 3, 191 pp., 2007.

Diederich, S.: Differential recruitment of introduced $\mathrm{Pa}$ cific oysters and native mussels at the North Sea coast: Coexistence possible?, J. Sea Res., 53, 269-281, https://doi.org/10.1016/j.seares.2005.01.002, 2005.

Feely, R. A., Sabine, C. L., Hernandez-Ayon, J. M., Ianson, D., and Hales, B.: Evidence for upwelling of corrosive "acidified" water onto the continental shelf, Science, 320, 1490-1492, https://doi.org/10.1126/science.1155676, 2008.

Feely, R. A., Doney, S. C., and Cooley, S. R.: Ocean acidification: Present conditions and future changes in a high- $\mathrm{CO}_{2}$ world, Oceanography, 22, 36-47, https://doi.org/10.5670/oceanog.2009.95, 2009.

Fu, F. X., Tatters, A. O., and Hutchins, D. A.: Global change and the future of harmful algal blooms in the ocean, Mar. Ecol.-Prog. Ser., 470, 207-233, https://doi.org/10.3354/meps10047, 2012.

Gao, K. and Zheng, Y.: Combined effects of ocean acidification and solar UV radiation on photosynthesis, growth, pigmentation and calcification of the coralline alga Corallina sessilis (Rhodophyta), Global Change Biol., 16, 2388-2398, https://doi.org/10.1111/j.1365-2486.2009.02113.x, 2010.

Garrard, S. L., Gambi, M. C., Scipione, M. B., Patti, F. P., Lorenti, M., Zupo, V., Paterson, D. M., and Buia, M. C.: Indirect effects may buffer negative responses of seagrass invertebrate communities to ocean acidification, J. Exp. Mar. Biol. Ecol., 461, 31-38, https://doi.org/10.1016/j.jembe.2014.07.011, 2014.

Gazeau, F., Quiblier, C., Jansen, J. M., Gattuso, J.-P., Middelburg, J. J., and Heip, C. H. R.: Impact of elevated $\mathrm{CO}_{2}$ on shellfish calcification, Geophys. Res. Lett., 34, L07603, https://doi.org/10.1029/2006GL028554, 2007.

Gobler, C. J. and Sunda, W. G.: Ecosystem disruptive algal blooms of the brown tide species, Aureococcus anophagefferens and Aureoumbra lagunensis, Harmful Algae, 14, 36-45, https://doi.org/10.1016/j.hal.2011.10.013, 2012.

Gobler, C. J. and Talmage, S. C.: Short- and long-term consequences of larval stage exposure to constantly and ephemerally elevated carbon dioxide for marine bivalve populations, Biogeosciences, 10, 2241-2253, https://doi.org/10.5194/bg-102241-2013, 2013.

Gobler, C. J., DePasquale, E. L., Griffith, A. W., and Baumann, H.: Hypoxia and acidification have additive and synergistic negative effects on the growth, survival, and metamorphosis of early life stage bivalves, PLoS ONE, 9, e83648, https://doi.org/10.1371/journal.pone.0083648, 2014.

Goldman, J. C. and Brewer, P. G.: Effect of nitrogen source and growth rate on phytoplankton-mediated changes in alkalinity, Limnol. Oceanogr., 25, 353-357, https://doi.org/10.4319/lo.1980.25.2.0352, 1980.

Green, M. A., Waldbusser, G. G., Reilly, S. L., Emerson, K., and O'Donnell, S.: Death by dissolution: sediment saturation state as a mortality factor for juvenile bivalves, Limnol. Oceanogr., 54, 1037-1047, https://doi.org/10.4319/lo.2009.54.4.1037, 2009.

Hattenrath-Lehmann, T. K., Smith, J. L., Wallace, R. B., Merlo, L. R., Koch, F., Mittelsdorf, H., Goleski, J. A., Anderson, D. M., and Gobler, C. J.: The effects of elevated $\mathrm{CO}_{2}$ on the growth and toxicity of field populations and cultures of the saxitoxin-producing dinoflagellate, Alexandrium fundyense, Limnol. Oceanogr., 60, 198-214, https://doi.org/10.1002/lno.10012, 2015.

Heck, K. L., Hays, G., and Orth, R. J.: Critical evaluation of the nursery role hypothesis for seagrass meadows, Mar. Ecol.-Prog. Ser., 253, 123-136, https://doi.org/10.3354/meps253123, 2003.

Helm, M. M., Bourne, N., and Lovatelli, A.: Hatchery Culture of Bivalves: A Practical Manual, Food and Agriculture Organization of the United Nations, Rome, 177 pp., 2004.

Hendriks, I. E., Olsen, Y. S., Ramajo, L., Basso, L., Steckbauer, A., Moore, T. S., Howard, J., and Duarte, C. M.: Photosynthetic activity buffers ocean acidification in seagrass meadows, Biogeosciences, 11, 333-346, https://doi.org/10.5194/bg-11-333-2014, 2014.

Hernández, I., Martínez-Aragón, J. F., Tovar, A., Pérez-Lloréns, J. L., and Vergara, J. J.: Biofiltering efficiency in removal of dissolved nutrients by three species of estuarine macroalgae cultivated with sea bass (Dicentratchus labrax) waste waters 2. Ammonium, J. Appl. Phycol., 14, 375-384, https://doi.org/10.1023/A:1022178417203, 2002.

Hoegh-Guldberg, O., Mumby, P. J., Hooten, A. J., Steneck, R. S., Greenfield, P., Gomez, E., Harvell, C. D., Sale, P. F., Edwards, A. J., Caldeira, K., Knowlton, N., Eakin, C. M., Iglesias-Prieto, R., Muthiga, N., Bradbury, R. H., Dubi, A., and Hatziolos, M. E.: Coral reefs under rapid climate change and ocean acidification, Science, 318, 1737-1742, https://doi.org/10.1126/science.1152509, 2007.

Hofmann, L. C., Nettleton, J. C., Neefus, C. D., and Mathieson, A. C.: Cryptic diversity of Ulva (Ulvales, Chlorophyta) in the Great Bay Estuarine System (Atlantic USA): introduced and indigenous distromatic species, Eur. J. Phycol., 45, 230-239, https://doi.org/10.1080/09670261003746201, 2010.

Johnson, D. A. and Welsh, B. L.: Detrimental effects of Ulva lactuca (L.) exudates and low oxygen on estuarine crab larvae, J. Exp. Mar. Biol. Ecol., 86, 73-83, https://doi.org/10.1016/00220981(85)90043-7, 1985.

Johnson, K. M., Wills, K. D., Butler, D. B., Johnson, W. K., and Wong, C. S.: Coulometric total carbon dioxide analysis for marine studies: maximizing the performance of an automated gas extraction system and coulometric detector, Mar. Chem., 44, 167-187, https://doi.org/10.1016/0304-4203(93)90201-X, 1993.

Kennedy, V. S., Newell, R. I. E., and Eble, A. E.: The Eastern oyster: Crassostrea virginica, College Park, MD, Maryland Sea Grant College, 1996.

Kirkendale, L., Saunders, G. W., and Winberg, P.: A molecular survey of Ulva (Chlorophyta) in temperate Australia reveals enhanced levels of cosmopolitanism, J. Phycol., 49, 69-81, https://doi.org/10.1111/jpy.12016, 2013.

Kleypas, J. A., Buddemeier, R. W., Archer, D., Gattuso, J.-P., Langdon, C., and Opdyke, B. N.: Geochemical consequences of in- 
creased atmospheric carbon dioxide on coral reefs, Science, 284, 118-120, https://doi.org/10.1126/science.284.5411.118, 1999.

Koch, M., Bowes, G., Ross, C., and Zhang, X.-H.: Climate change and ocean acidification effects on seagrasses and marine macroalgae, Global Change Biol., 19, 103-132, 2013.

Kraeuter, J. N. and Castagna, M.: Biology of the Hard Clam, Elsevier Science, New York, NY, 2001.

Krause-Jensen, D., Duarte, C. M., Hendriks, I. E., Meire, L., Blicher, M. E., Marbà, N., and Sejr, M. K.: Macroalgae contribute to nested mosaics of $\mathrm{pH}$ variability in a subarctic fjord, Biogeosciences, 12, 4895-4911, https://doi.org/10.5194/bg-124895-2015, 2015.

Leverone, J. R., Blake, N. J., Pierce, R. H., and Shumway, S. E.: Effects of the dinoflagellate Karenia brevis on larval development in three species of bivalve mollusc from Florida, Toxicon, 48, 75-84, https://doi.org/10.1016/j.toxicon.2006.04.012, 2006.

Liu, X., Li, Y., Wang, Z., Zhang, Q., and Cai, X.: Cruise observation of Ulva prolifera bloom in the southern Yellow Sea, China, Estuar. Coast. Shelf Sci., 163, 17-22, https://doi.org/10.1016/j.ecss.2014.09.014, 2015.

Magre, E. J.: Ulva lactuca L. negatively affects Balanus balanoides (L.) (Cirripedia Thoracica) in tidepools, Crustaceana, 27, 231234, https://doi.org/10.1163/156854074X00758, 1974.

Martin, S. and Gattuso, J.-P.: Response of Mediterranean coralline algae to ocean acidification and elevated temperature, Global Change Biol., 15, 2089-2100, https://doi.org/10.1111/j.13652486.2009.01874.x, 2009.

Matoo, O. B., Ivanina, A. V., Ullstad, C., Beniash, E., and Sokolova, I. M.: Interactive effects of elevated temperature and $\mathrm{CO}_{2}$ levels on metabolism and oxidative stress in two common marine bivalves (Crassostrea virginica and Mercenaria mercenaria), Comp. Biochem. Physiol. A., 164, 545-553, https://doi.org/10.1016/j.cbpa.2012.12.025, 2013.

McGlathery, K. J.: Macroalgal blooms contribute to the decline of seagrass in nutrient-enriched coastal waters, J. Phycol., 37, 453456, https://doi.org/10.1046/j.1529-8817.2001.037004453.x, 2001.

Meehl, G. A., Stocker, T. F., Collins, W. D., Friedlingstein, P., Gaye, A. T., Gregory, J. M., Kitoh, A., Knutti, R., Murphy, J. M., Noda, A., Raper, S. C. B., Watterson, I. G., Weaver, A. J., and Zhao, Z.-C.: Global Climate Projections, Cambridge University Press, Cambridge, 747-845, 2007.

Melzner, F., Jörn, T., Koeve, W., Oschlies, A., Gutowska, M. A., Bange, H. W., Hansen, H. P., and Körtzinger, A.: Future ocean acidification will be amplified by hypoxia in coastal habitats, Mar. Biol., 160, 1875-1888, https://doi.org/10.1007/s00227012-1954-1, 2013.

Millero, F. J.: History of the equation of state of seawater, Oceanography, 23, 18-33, https://doi.org/10.5670/oceanog.2010.21, 2010.

Nelson, T. A., Lee, D. J., and Smith, B. C.: Are "green tides" harmful algal blooms? Toxic properties of water-soluble extracts from two bloom-forming macroalgae, Ulva fenestrate and Ulvaria obscura (Ulvophyceae), J. Phycol., 39, 874-879, https://doi.org/10.1046/j.1529-8817.2003.02157.x, 2003.

Neori, A.: Essential role of seaweed cultivation in integrated multi-trophic aquaculture farms for global expansion of mariculture: an analysis, J. Appl. Phycol., 20, 567-570, https://doi.org/10.1007/s10811-007-9206-3, 2008.
Neori, A., Msuya, F. E., Shauli, L., Schuenhoff, A., Kopel, F., and Shpigel, M.: A novel three-stage seaweed (Ulva lactuca) biofilter design for integrated mariculture, J. Appl. Phycol., 15, 543-553, https://doi.org/10.1023/B:JAPH.0000004382.89142.2d, 2003.

Newell, R. I. E.: Ecosystem influences of natural and cultivated populations of suspension-feeding bivalve molluscs: A review, J. Shellfish Res., 23, 51-61, 2004.

Nobre, A. M., Robertson-Andersson, D., Neori, A., and Sankar, K.: Ecological-economic assessment of aquaculture options: Comparison between abalone monoculture and integrated multitrophic aquaculture of abalone and seaweeds, Aquaculture, 306, 116-126, https://doi.org/10.1016/j.aquaculture.2010.06.002, 2010.

Olischläger, M., Bartsch, I., Gutow, L., and Wiencke, C.: Effects of ocean acidification on growth and physiology of Ulva lactuca (Chlorophyta) in a rockpool-scenario, Phycological Res., 61, 180-190, https://doi.org/10.1111/pre.12006, 2013.

Orth, R. J., Carruthers, T. J. B., Dennison, W. C., Duarte, C. M., Fourqurean, J. W., Heck, K. L., Hughes, A. R., Kendrick, G. A., Kenworthy, W. J., Olyarnik, S., Short, F. T., Waycott, M., and Williams, S. L.: A global crisis for seagrass ecosystems, BioScience, 56, 987-996, https://doi.org/10.1641/00063568(2006)56[987:agcfse]2.0.co;2, 2006.

Palacios, S. L. and Zimmerman, R. C.: Response of eelgrass Zostera marina to $\mathrm{CO}_{2}$ enrichment: possible impacts of climate change and potential for remediation of coastal habitats, Mar. Ecol.Prog. Ser., 344, 1-13, https://doi.org/10.3354/meps07084, 2007.

Pedersen, M. F. and Borum, J.: Nutrient control of estuarine macroalgae: growth strategy and the balance between nitrogen requirements and uptake, Mar. Ecol.-Prog. Ser., 161, 155-163, https://doi.org/10.3354/meps161155, 1997.

Redfield, A. C., Ketchum, B. H., and Richards, F. A.: The influence of organisms on the composition of sea water, in: The Sea, edited by: Hill, M. N., Interscience, New York, 1963.

Salisbury, J., Green, M., Hunt, C., and Campbell, J.: Coastal acidification by rivers: a new threat to shellfish?, Eos Trans. AGU, 89, 513, https://doi.org/10.1029/2008EO500001, 2008.

Sfriso, A., Birkemeyer, T., and Ghetti, P. F.: Benthic macrofauna changes in areas of Venice lagoon populated by seagrasses or seaweeds, Mar. Environ. Res., 52, 323-349, https://doi.org/10.1016/S0141-1136(01)00089-7, 2001.

Short, F. T., Polidoro, B., Livingstone, S. R., Carpenter, K. E., Bandeira, S., Bujang, J. S., Calumpong, H. P., Carruthers, T. J. B., Coles, R. G., Dennison, W. C., Erftemeijer, P. L. A., Fortes, M. D., Freeman, A. S., Jagtap, T. G., Kamal, A. H. M., Kendrick, G. A., Kenworthy, W. J., Nafie, Y. A. L., Nasution, I. M., Orth, R. J., Prathep, A., Sanciangco, J. C., van Tussenbroek, B., Vergara, S. G., Waycott, M., and Zieman, J. C.: Extinction risk assessment of the world's seagrass species, Biol. Cons., 144, 19611971, https://doi.org/10.1016/j.biocon.2011.04.010, 2011.

Shumway, S. E. and Parsons, G. J.: Scallops: Biology, Ecology, and Aquaculture, Elsevier, Boston, MA, 2006.

Smetacek, V. and Zingone, A.: Green and golden seaweed tides on the rise, Nature, 504, 84-88, https://doi.org/10.1038/nature12860, 2013.

Sogard, S. M. and Able, K. W.: A comparison of eelgrass, sea lettuce macroalgae, and marsh creeks as habitats for epibentic fishes and decapods, Estuar. Coast. Shelf Sci., 33, 501-519, https://doi.org/10.1016/0272-7714(91)90087-R, 1991. 
Stenzel, H. B.: Oysters: Composition of the larval shell, Science, 304, 1005-1008, https://doi.org/10.1126/science.145.3628.155, 1964.

Stevens, A. M. and Gobler, C. J.: Interactive effects of acidification, hypoxia, and thermal stress on growth, respiration, and survival of four North Atlantic bivalves, Mar. Ecol.-Prog. Ser., 604, 143161, https://doi.org/10.3354/meps12725, 2018.

Stoecker, D. K., Adolf, J. E., Place, A. R., Glibert, P. M., and Meritt, D. W.: Effects of the dinoflagellates Karlodinium veneficum and Prorocentrum minimum on early life history stages of the eastern oyster (Crassostrea virginica), Mar. Biol., 154, 8190, https://doi.org/10.1007/s00227-007-0901-z, 2008.

Talmage, S. C. and Gobler, C. J.: The effects of elevated carbon dioxide concentrations on the metamorphosis, size, and survival of larval hard clams (Mercenaria mercenaria), bay scallops (Argopecten irradians), and Eastern oysters (Crassostrea virginica), Limnol. Oceanogr., 54, 2072-2080, https://doi.org/10.4319/lo.2009.54.6.2072, 2009.

Talmage, S. C. and Gobler, C. J.: Effects of past, present, and future ocean carbon dioxide concentrations on the growth and survival of larval shellfish, P. Natl. Acad. Sci. USA, 107, 17246-17251, https://doi.org/10.1073/pnas.0913804107, 2010.

Talmage, S. C. and Gobler, C. J.: Effects of elevated temperature and carbon dioxide on the growth and survival of larvae and juveniles of three species of northwest Atlantic bivalves, PLoS ONE, 6, e26941, https://doi.org/10.1371/journal.pone.0026941, 2011.

Talmage, S. C. and Gobler, C. J.: Effects of $\mathrm{CO}_{2}$ and the harmful alga Aureococcus anophagefferens on growth and survival of oyster and scallop larvae, Mar. Ecol.-Prog. Ser., 464, 121-134, https://doi.org/10.3354/meps09867, 2012.

Tang, Y. Z. and Gobler, C. J.: Cochlodinium polykrikoides blooms and clonal isolates from the northwest Atlantic coast cause rapid mortality in larvae of multiple bivalve species, Mar. Biol., 156, 2601-2611, https://doi.org/10.1007/s00227-009-1285-z, 2009.

Tang, Y. Z. and Gobler, C. J.: The green macroalga, Ulva lactuca, inhibits the growth of seven common harmful algal bloom species via allelopathy, Harmful Algae, 10, 480-488, https://doi.org/10.1016/j.hal.2011.03.003, 2011.

Tang, Y. Z., Kang, Y., Berry, D., and Gobler, C. J.: The ability of the red macroalga, Porphyra purpurea (Rhodophyceae) to inhibit the proliferation of seven common harmful microalgae, J. Appl. Phycol., 27, 531-544, https://doi.org/10.1007/s10811-014-0338y, 2015.

Thomsen, J., Casties, I., Pansch, C., Körtzinger, A., and Melzner, F.: Food availability outweighs ocean acidification effects in juvenile Mytilus edulis: laboratory and field experiments, Global Change Biol., 19, 1017-1027, https://doi.org/10.1111/gcb.12109, 2013.

Troell, M., Joyce, A., Chopin, T., Neori, A., Buschmann, A. H., and Fang, J.-G.: Ecological engineering in aquaculture - Potential for integrated multi-trophic aquaculture (IMTA) in marine offshore systems, Aquaculture, 297, 1-9, https://doi.org/10.1016/j.aquaculture.2009.09.010, 2009.

Tyler, R. M.: Effects of coverage by benthic seaweed mats on (northern quahog $=$ hard clam) Mercenaria mercenaria in a eutrophic estuary, J. Shellfish Res., 26, 1021-1028, https://doi.org/10.2983/07308000(2007)26[1021:EOCBBS]2.0.CO;2, 2007.
Valiela, I., Foreman, K., LaMontagne, M., Hersh, D., Costa, J., Peckol, P., DeMeo-Andreson, B., D’Avanzo, C., Babione, M., Sham, C.-H., Brawley, J., and Lajtha, K.: Couplings of watersheds and coastal waters: Sources and consequences of nutrient enrichment in Waquoit Bay, Massachusetts, Estuaries, 15, 443 457, https://doi.org/10.2307/1352389, 1992.

Valiela, I., McClelland, J., Hauxwell, J., Behr, P. J., Hersh, D., and Foreman, K.: Macroalgal blooms in shallow estuaries: Controls and ecophysiological and ecosystem consequences, Limnol. Oceanogr., 42, 1105-1118, https://doi.org/10.4319/lo.1997.42.5_part_2.1105, 1997.

Viaroli, P., Azzoni, R., Bartoli, M., Giordano, G., and Tajé, L.: Evolution of the Trophic Conditions and Dystrophic Outbreaks in the Sacca di Goro Lagoon (Northern Adriatic Sea), in: Mediterranean Ecosystems, edited by: Faranda, F. M., Guglielmo, L., and Spezie, G., Springer, Milano, 467-475, 2001.

Wahl, M., Schneider Covachã, S., Saderne, V., Hiebenthal, C., Müller, J. D., Pansch, C., and Sawall, Y.: Macroalgae may mitigate ocean acidification effects on mussel calcification by increasing $\mathrm{pH}$ and its fluctuations, Limnol. Oceanogr., 63, 3-21, https://doi.org/10.1002/lno.10608, 2017.

Waldbusser, G. G., Bergschneider, H., and Green, M. A.: Size-dependent $\mathrm{pH}$ effect on calcification in post-larval hard clam Mercenaria spp., Mar. Ecol.-Prog. Ser., 417, 171-182, https://doi.org/10.3354/meps08809, 2010.

Waldbusser, G., Hales, B., Langdon, C. J., Haley, B. A., Schrader, P., Brunner, E. L., Gray, M. W., Miller, C. A., and Gimenez, I.: Saturation-state sensitivity of marine bivalve larvae to ocean acidification, Nat. Clim. Change, 5, 273-280, https://doi.org/10.1002/grl.50449, 2015a.

Waldbusser, G. G., Hales, B., Langdon, C., Haley, B. A., Schrader, P., Brunner, E. L., Gray, M. W., Miller, C. A., Gimenez, I., and Hutchins, D. A.: Ocean acidification has multiple modes of action on bivalve larvae, PLoS ONE, 10, e0128376, https://doi.org/10.1371/journal.pone.0128376, 2015 b.

Wallace, R. B. and Gobler, C. J.: Factors controlling blooms of microalgae and macroalgae (Ulva rigida) in a eutrophic, urban estuary: Jamaica Bay, NY, USA, Estuar. Coast., 38, 519-533, https://doi.org/10.1007/s12237-014-9818-1, 2015.

Wallace, R. B., Baumann, H., Grear, J. S., Aller, R. C., and Gobler, C. J.: Coastal ocean acidification: The other eutrophication problem, Estuar. Coast. Shelf Sci., 148, 1-13, https://doi.org/10.1016/j.ecss.2014.05.027, 2014.

Wang, C., Yu, R.-C., and Zhou, M.-J.: Acute toxicity of live and decomposing green alga Ulva (Enteromorpha) prolifera to abalone Haliotis discus hannai, Chinese J. Oceanol. Limnol., 29, 541546, https://doi.org/10.1007/s00343-011-0126-3, 2011.

Ward, J. E. and Shumway, S. E.: Separating the grain from the chaff: particle selection in suspension- and depositfeeding bivalves, J. Exp.Mar. Bio. Ecol., 300, 83-130, https://doi.org/10.1016/j.jembe.2004.03.002, 2004.

Waycott, M., Duarte, C. M., Caruthers, T. J. B., Orth, R. J., Dennison, W. C., Olyarnik, S., Calladine, A., Fourqurean, J. W., Heck, K. L., Hughes, A. R. A., Kendrick, G. A., Kenworthy, W. J., Short, F. T., and Williams, S. L.: Accelerating loss of seagrasses across the globe threatens coastal ecosystems, P. Natl. Acad. Sci. USA, 106, 12377-12381, https://doi.org/10.1073/pnas.0905620106, 2009. 
Weiss, I. M., Tuross, N., Addadi, L., and Weiner, S.: Mollusc larval shell formation: Amorphous calcium carbonate is a precursor phase for aragonite, J. Exp. Zool., 293, 478-491, https://doi.org/10.1002/jez.90004, 2002.

Wilson, K. A., Able, K. W., and Heck Jr., K. L.: Predation rates on juvenile blue crabs in estuarine nursery habitats: evidence for the importance of macroalgae (Ulva lactuca), Mar. Ecol.-Prog. Ser., 58, 243-251, https://doi.org/10.3354/meps058243, 1990.

Young, C. S. and Gobler, C. J.: Ocean acidification accelerates the growth of two bloom-forming, estuarine macroalgae, PLoS ONE, 11, e0155152, https://doi.org/10.1371/journal.pone.0155152, 2016.
Young, C. S. and Gobler, C. J.: The organizing effects of elevated $\mathrm{CO}_{2}$ on competition among estuarine primary producers, Sci. Rep.-UK, 7, 7667, https://doi.org/10.1038/s41598-017-08178-5, 2017.

Young, C. S., Peterson, B. J., and Gobler, C. J.: The bloom forming macroalgae, Ulva, outcompetes the seagrass, Zostera marina, under high $\mathrm{CO}_{2}$ conditions, Estuar. Coast., 1-16, https://doi.org/10.1007/s12237-018-0437-0, 2018.

Zimmerman, R. C., Kohrs, D. G., Steller, D. L., and Alberte, R. S.: Impacts of $\mathrm{CO}_{2}$ enrichment on productivity and light requirements of eelgrass, Plant Physiol., 115, 599-607, https://doi.org/10.1104/pp.115.2.599, 1997. 